\title{
Phosphatidylinositol-3-Kinase-Atypical Protein Kinase C Signaling Is Required for Wnt Attraction and Anterior-Posterior Axon Guidance
}

\author{
Alex M. Wolf, ${ }^{2 \star}$ Anna I. Lyuksyutova, ${ }^{2 \star}$ Ali G. Fenstermaker, ${ }^{3,4}$ Beth Shafer, ${ }^{3}$ Charles G. Lo, ${ }^{3}$ and Yimin Zou ${ }^{1,2,3,4}$ \\ ${ }^{1}$ Department of Neurobiology, Pharmacology, and Physiology and ${ }^{2}$ Committee on Developmental Biology, The University of Chicago, Chicago, Illinois \\ 60637, and ${ }^{3}$ Neurobiology Section, Biological Sciences Division, and ${ }^{4}$ Neuroscience Program, University of California, San Diego, La Jolla, California 92093
}

\begin{abstract}
Wnt proteins are conserved axon guidance cues that control growth cone navigation. However, the intracellular signaling mechanisms that mediate growth cone turning in response to Wnts are unknown. We previously showed that Wnt-Frizzled signaling directs spinal cord commissural axons to turn anteriorly after midline crossing through an attractive mechanism. Here we show that atypical protein kinase $\mathrm{C}(\mathrm{aPKC})$, is required for Wnt-mediated attraction of commissural axons and proper anterior-posterior (A-P) pathfinding. A $\mathrm{PKC} \zeta$ pseudosubstrate, a specific blocker of aPKC activity, and expression of a kinase-defective $\mathrm{PKC} \zeta$ mutant in commissural neurons resulted in A-P randomization in "open-book" explants. Upstream of $\mathrm{PKC} \zeta$, heterotrimeric G-proteins and phosphatidylinositol-3kinases (PI3Ks), are also required for A-P guidance, because pertussis toxin, wortmannin, and expression of a p110 $\gamma$ kinase-defective construct all resulted in A-P randomization. Overexpression of $110 \gamma$, the catalytic subunit of PI $3 \mathrm{~K} \gamma$, caused precocious anterior turning of commissural axons before midline crossing in open-book explants and caused dissociated precrossing commissural axons, which are normally insensitive to Wnt attraction, to turn toward Wnt4-expressing cells. Therefore, we propose that atypical PKC signaling is required for Wnt-mediated A-P axon guidance and that PI3K can act as a switch to activate Wnt responsiveness during midline crossing.
\end{abstract}

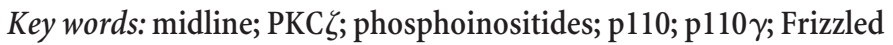

\section{Introduction}

Wnts are conserved signaling proteins that play a number of roles in early development, including patterning and cell fate determination (Logan and Nusse, 2004). They are also essential for later processes in nervous system development, such as cell migration, neuronal polarization, axon guidance, dendrite morphogenesis, and synapse formation (Ciani and Salinas, 2005; Fradkin et al., 2005).

Although many studies have demonstrated that Wnts guide axons in development, the intracellular signaling mechanisms are currently unknown (Lyuksyutova et al., 2003; Yoshikawa et al., 2003; Lu et al., 2004; Zou, 2004, 2006; Liu et al., 2005; Hilliard and Bargmann, 2006; Pan et al., 2006; Prasad and Clark, 2006; Sato et al., 2006; Schmitt et al., 2006; Zou and Lyuksyutova, 2007). We found that Wnt signaling controls anterior-posterior guidance of commissural axons after midline crossing (Lyuksyutova et al., 2003). Three major Wnt pathways have been described: the canonical/ $\beta$-catenin, planar cell polarity (PCP), and calcium/

\footnotetext{
Received Nov. 13, 2007; revised Feb. 7, 2008; accepted Feb. 11, 2008.

This work was supported by National Institute of Neurological Disorders and Stroke Grant R01-NS47484 (Y.Z.) and Individual Predoctoral National Research Service Award 1F31-NS049753 (A.L.). We thank A. Toker for the wild-type and kinase-dead PKC $\zeta$ constructs, M. Wymann for the p110 $\gamma$-KD construct, and F. G. Rathjen for the anti-L1 antibody. We also thank members of the Zou laboratory L. A. King, L. M. Parra, A. Richman, A. Bechara, and D. Delaunay for comments and suggestions on this manuscript.

*A.M.W. and A.I.L. contributed equally to this work.

Correspondence should be addressed to Yimin Zou at the above address. E-mail: yzou@ucsd.edu.

DOI:10.1523/JNEUROSCI.0029-08.2008

Copyright $\odot 2008$ Society for Neuroscience $\quad 0270-6474 / 08 / 283456-12 \$ 15.00 / 0$
}

protein kinase C (PKC) pathways. Low-density lipoprotein receptor-related protein 5 (LRP5) and LRP6 are indispensable components of canonical/ $\beta$-catenin Wnt signaling ( $\mathrm{He}$ et al., 2004). We observed that A-P guidance of commissural axons appeared normal in embryonic day 11.5 (E11.5) LRP6-deficient spinal cords (Lyuksyutova et al., 2003). The addition of the LRP5/6 inhibitor, DKK1 (Dikkopf1), also had no effect on A-P guidance in "open-book" explants (our unpublished observations). These results suggest that the canonical Wnt signaling pathway does not play a major role in A-P guidance of commissural axons.

The Wnt/calcium/PKC pathway controls cell migration (Cohen et al., 2002), and calcium-dependent PKCs have been implicated in embryonic growth cone guidance in vitro and inhibition of adult axon regeneration (Xiang et al., 2002; Sivasankaran et al., 2004). Therefore, we tested the role of the PKCs in Wnt-mediated anterior turning of commissural axons and identified several intracellular signaling components required in Wnt-dependent growth cone attraction. Treatment with myristoylated PKC $\zeta$ pseudosubstrate, a potent and specific inhibitor of atypical PKCs (aPKCs), resulted in randomization of commissural axon growth along the A-P axis and blocked Wnt4-mediated attraction, whereas expression of a kinase-defective form of PKC $\zeta$ caused A-P randomization of commissural axons in open-book explants. Because $\mathrm{PKC} \zeta$ is activated by inositol phospholipid signaling and Frizzleds are putative G-protein-coupled receptors (GPCRs), we examined the roles of PI3K and heterotrimeric 
G-proteins in this process. Several members of the PI3K family are expressed in the mouse and rat embryonic spinal cord. We found that both PI3K and heterotrimeric G-proteins are required for proper anterior-posterior guidance of spinal cord commissural axons. Expression of a kinase-defective p $110 \gamma$, the catalytic domain of PI3K $\gamma$, caused randomized growth of commissural axons after midline crossing. Overexpression of p110 $\gamma$ in an open-book preparation (Martiny-Baron et al., 1993; Lyuksyutova et al., 2003) caused precrossing commissural axons to turn anteriorly before entering the floor plate (FP). Expression of p110 $\gamma$ in dissociated precrossing commissural neurons that are normally insensitive to Wnt attraction caused them to respond to Wnt4-expressing COS cells. Thus, p110 $\gamma$ appears to be a component of the "switch" mechanism, allowing Wnt responsiveness to occur after midline crossing.

\section{Materials and Methods}

Reagents. Pharmacological inhibitors and PKC pseudosubstrates were purchased from various vendors, and the concentrations used in the explant assays are indicated: GF-109203X (14 $\mu \mathrm{M}$; catalog \#270-019M001; Alexis Biochemicals, San Diego CA), Gö-6967 (124 nм for openbook explants and $12.4 \mathrm{~nm}$ for "postcrossing assays"; catalog \#365250;

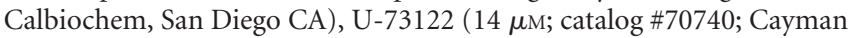
Chemical, Ann Arbor MI), neomycin sulfate (55 $\mu \mathrm{M}$; catalog \#El180; Biomol, Plymouth Meeting, PA), myristoylated PKC pseudosubstrates $\alpha$ (50 $\mu \mathrm{M}$; catalog \#P-205; Biomol) and $\zeta(50 \mu \mathrm{M}$; catalog \#P-219; Biomol), pertussis toxin (800 ng/ml; catalog \#P-2980; Sigma, St. Louis, MO), wortmannin ( $1 \mu \mathrm{M}$; catalog \#ST-415; Biomol), lithium chloride (10 mM; catalog \#L4408; Sigma), and SB-216763 (10 $\mu \mathrm{M}$; catalog \#S3442; Sigma). Different drugs have different chemical properties, and their concentrations used in experiments are determined empirically. Most of the publications involving these inhibitors are in cell-free kinase assays in vitro. In order for them to diffuse into the cells to block signaling, a higher concentration than that used in in vitro assays is needed, and open-book assays require higher concentrations than postcrossing assays, because the axons are more accessible in the collagen gel in the latter case. We performed a titration initially and used the lowest concentrations for each inhibitor. In general, we used concentrations that are either equivalent or severalfold higher than used in in vitro assays published in literature.

The following antibodies were purchased from vendors: PKC $\zeta$ (rabbit polyclonal; catalog \#s.c.-216; Santa Cruz Biotechnology, Santa Cruz,

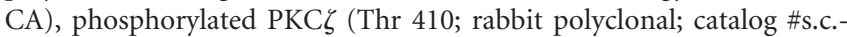
12894; Santa Cruz Biotechnology), PAR6 (goat polyclonal; catalog \#s.c.14405; Santa Cruz Biotechnology), GSK3 $\beta$ (catalog \#AB8687; Millipore, Billerica, MA), GSK3 $\beta$ pS9 (catalog \#44-600G; Biosource, Carlsbad $\mathrm{CA}$ ), enhanced green fluorescent protein (EGFP; rabbit polyclonal; catalog \#A111122; Invitrogen, Carlsbad, CA) and $\beta$-tubulin E7 (Developmental Studies Hybridoma Bank, University of Iowa, Iowa City, IA). TAG-1 was produced in our lab from cells obtained from Developmental Studies Hybridoma Bank (cell line \#4D7/TAG-1; University of Iowa). L1 antibodies were a kind gift from Dr. Rathjen. Our secondary antibodies were obtained from Invitrogen.

DNA constructs. A kinase-defective construct of PKC $\zeta$ was kindly provided by Alex Toker (Harvard University, Boston, MA) (Romanelli et al., 1999). A point mutation at a conserved lysine residue to tryptophan in the ATP-binding domain inactivates the kinase activity of PKC $\zeta$ and can partially inhibit signaling activated by both EGF and a constitutively active mutant of PI3K. This mutant construct was cloned into pCIG2 vector followed by internal ribosomal entry sequence (IRES) GFP via the $E c o$ RI site. pCIG2 has the chick $\beta$-actin promoter with a CMV enhancer and gives high levels of expression in neurons. The p110 $\gamma$ full-length gene (GenBank accession number AF208345) was amplified from an E11.5 whole-embryo mouse cDNA library. The PCR product was cloned into the EGFP-N2 vector (Clontech, Mountain View, CA) modified to include the chick $\beta$-actin promoter, producing a full-length p $110 \gamma-\mathrm{N}$ terminal EGFP fusion. The mouse $\mathrm{p} 110 \gamma$-K799R point mutation was created by site-directed mutagenesis in the lab and verified by sequencing. The coding sequence was cloned into pIRES2 modified with the chick $\beta$-actin promoter.

Immunohistochemistry. E11.5 mouse embryos and cultured rat postcrossing explants were first fixed in $4 \%$ paraformaldehyde (PFA) for $2 \mathrm{~h}$, embedded in OCT compound, and sectioned at $10 \mu \mathrm{m}$. Slides were washed in PBS, then incubated in $1 \%$ or $5 \%$ donkey serum and $0.1 \%$ Triton in PBS for 2-3 h at room temperature. Antibodies were diluted in the blocking solution, and the slides were incubated in primary antibody for $24 \mathrm{~h}$ at $4^{\circ} \mathrm{C}$. The concentrations of primary antibodies used were as follows: PKC $\zeta, 1: 1000$; pPKC $\zeta, 1: 50$; PAR6, 1:50; GSK3 $\beta, 1: 100$; GSK3 $\beta$ pS9, 1:100; TAG-1, 1:50; L1-1,1000. The slides were washed three times for 10 min each in PBS and then incubated for $2 \mathrm{~h}$ in 1:1000 secondary antibody, washed again, and mounted using Fluoromount G. Pictures were taken using a Zeiss (Thornwood, NY) LSM510 confocal microscope.

Pharmacological treatment of explants. Open-book or postcrossing explants were prepared as previously described (Zou et al., 2000; Lyuksyutova et al., 2003). At $\sim 6-8 \mathrm{~h}$ of culture, explants were treated with a pharmacological or peptide inhibitor or a control treatment. After another $10-12 \mathrm{~h}$ of incubation, explants were fixed with warm $4 \%$ PFA. For open-book preparations, axons were visualized using iontophoretic injection of lipophilic 3,3'-dihexadecylindocarbocyanine (DiI) at onethird to one-fourth from the dorsal margin of the spinal cord. We have characterized the rodent and chick commissural neuron projections extensively and found that most of the rodent axons labeled by this dorsal injection turn anteriorly after midline crossing. Injection sites more ventral to this will label many axons that will turn posteriorly after crossing, as well as those that turn anteriorly. It should be noted that in chick spinal cord, only the injection sites at the dorsalmost spinal cord (right adjacent to the roof plat) turn anteriorly, and DiI injection into one-third and one-fourth from the dorsal margin of the spinal cord will label many posterior axons. We performed our studies on A-P guidance in rodents. One injection site per explant was usually performed, which was placed in the middle of the explant's length because we found previously that in open-book explants, axons close to the anterior ends of longer explants $(3 \mathrm{~mm})$ are often misguided, presumably because of the loss of Wnt gradient caused by protein diffusion (Lyuksyutova et al., 2003). After allowing DiI to diffuse along the axon, the explants were photographed using Zeiss Axioplan and the OpenLab software (Improvision, Waltham, MA). Because each DiI injection labels a cohort of axons, we scored injection sites based on overall axonal behavior as previously described (Zou et al., 2000; Lyuksyutova et al., 2003). If all axons turned anteriorly in one injection, the injection site was scored "anterior (correct) turn"; if $75-80 \%$ axons stalled immediately after midline, unable to make a turning decision either anterior or posterior, we classified the injection site as "stalling"; if 50\% (or more) axons projected randomly ( $25 \%$ anterior and $25 \%$ posterior) after floor plate exit, it was counted as "random turn $(\mathrm{A} / \mathrm{P})$ ". If significant stalling and random turn $(\mathrm{A} / \mathrm{P})$ phenotypes were observed, the injection site was classified as random turn $(\mathrm{A} / \mathrm{P})$. The frequency of each category was presented as a percentage of all injected sites. At least three sets of experiments were performed for each experimental condition. A total of 15 and 23 explants were quantified in control and GF-109203X-treated conditions, respectively; 19 and 25 explants in control and Gö-6976; 24 and 25 explants in control and PKC $\zeta$ pseudosubstrate treatment; 31,29 , and 28 explants in control, lithium chloride (LiCl), and SB-216763 treatment; 9 and 20 explants in control and pertussis toxin treatment; and 13 and 11 explants in control and wortmannin-treated conditions. $p$ values were calculated using Student's $t$ test, assuming paired and two-tailed distributions. $p$ values presented compare percentage of correctly turning injection sites in untreated and treated explants.

For postcrossing assays, experiments were performed as described previously (Zou et al., 2000; Lyuksyutova et al., 2003). One side of the spinal cord segment was cut off right at the edge of the floor plate, leaving the floor plate attached to the other half of the spinal cord. As characterized in previous studies, these axons that grow out of the explants into the collagen gel are commissural axons that have crossed the midline, thus the name postcrossing assay (Zou et al., 2000). The explants were fixed 
with warm $4 \%$ PFA after $16 \mathrm{~h}$ of culture, immunostained with $\beta$-tubulin E7 antibody, and visualized by DAB color reaction with a secondary antibody conjugated to HRP. The explants were photographed at the same magnification using a Zeiss AxioPlan2 microscope with OpenLab software. For quantification, the area of total axon outgrowth was measured for each explant using NIH ImageJ software and averaged over all the experiments for control and treatment groups. To measure the area of outgrowth, each image was turned into a black-and-white composite using the Threshold function. Each experimental set was quantified using the same threshold parameters. The total area of black pixels was measured using the Analyze Particles function, and then the particles showing axonal outgrowth were erased using the Eraser tool. The total area of black particles was measured again, and the difference was recorded as total area of axonal outgrowth. The measurements for each explant in a set were averaged, and in the cases of pertussis toxin (PTX), wortmannin, $\mathrm{LiCl}$, and SB-216763, the ratios of outgrowth of experimental conditions compared with control condition were calculated. Three sets of experiments for each condition were performed, and the resulting ratios or area outgrowth were averaged. SDs were calculated based on these sets of experiments. A total of 27, 16, 16, and 16 explants were tested in vector only, vector only with GF-109203X, Wnt4, and Wnt4 with GF-109203X; 27, 23, 16, and 16 explants were tested in vector only, vector only with Gö-6976, Wnt4, and Wnt4 with Gö-6976; 25, 23, 31 , and 30 explants were tested in vector only, vector only with PKC $\zeta$ pseudosubstrate, Wnt4, and Wnt4 with PKC $\zeta$ pseudosubstrate; 22, 18, 24 , and 24 explants were tested with vector only, vector only with pertussis toxin, Wnt4, and Wnt4 with pertussis toxin; 21, 16, 27, and 23 explants were tested with vector only, vector only with wortmannin, Wnt4, and Wnt 4 with wortmannin; 26, 23, 28, and 24 explants were tested in vector only, vector only with $\mathrm{LiCl}$, Wnt 4 , and Wnt4 with $\mathrm{LiCl} ; 14,15,23$, and 17 explants were tested in vector only, vector only with SB-216763, Wnt4, and Wnt 4 with SB-216763-treated conditions. $p$ values were calculated using Student's $t$ test, assuming paired and two-tailed distributions. $p$ values presented compare average outgrowth from untreated and treated explants grown in the presence of Wnt4.

Ex utero electroporation of rat spinal cord. E13 rat embryos were eviscerated, and the notochord was removed. Using a pulled glass needle, control or experimental DNA was injected into the neural tube at a concentration of $1 \mu \mathrm{g} / \mu \mathrm{l}$. Using $5 \mathrm{~mm}$ gold-plated electrodes (\#45-0115; Harvard Apparatus, South Natick, MA), square-wave current was passed across the dorsal neural tube using BTX \#ECM 830 electroporator. Electroporation conditions were as follows: five pulses, $25 \mathrm{~V}, 100 \mathrm{~ms}$ pulse, $1 \mathrm{~s}$ interval. After electroporation, the spinal cord was dissected and openbook explants were cultured in a three-dimensional collagen matrix for $60 \mathrm{~h}$. When we electroporated the spinal cord from the ventricular zone at E13, the cells that take up DNA were still in the ventricular zone. It takes $1-2 \mathrm{~d}$ for them to differentiate and migrate to the spinal cord mantle zone and project axons. In vivo, commissural neurons develop in a span of at least 3-4 d (from E10.5 to E14.5 in mouse and E13 to E16/17 in rat). Because of the small size of the spinal cord and fragility of the tissue, we cannot dissect and culture spinal cord tissues younger than E13, let alone electroporate and then dissect them. However, this should not affect our study because these axons behave in culture very similarly to in vivo. Our previous studies indicate that the axons from the dorsal commissural neurons (one-third to one-fourth) at this stage rely on Wnt signaling to turn anteriorly (Lyuksyutova et al., 2003).

After culture, explants were fixed with $4 \% \mathrm{PFA}$ at $37^{\circ} \mathrm{C}$. After fixation, explants were removed from collagen matrix and blocked with $5 \%$ normal donkey serum, $1 \%$ bovine serum albumin, and $1 \%$ Triton X-100 overnight. This was followed by overnight incubation with primary antibody, $\alpha$-GFP (1:7500). Explants were washed for 4-6 h with multiple $1 \times$ PBS washes and incubated with secondary antibody Alexa Fluor 488 $\alpha$-rabbit IgG overnight. After multiple washes, explants were mounted using Fluoromount $\mathrm{G}$ between two coverslips for microscopic analysis using Zeiss LSM510 confocal laser-scanning microscope. For quantification, four separate experiments were performed using PKC $\zeta$ constructs, where total number of axons counted was 87 for EGFP-electroporated explants, 97 for kinase-defective $\mathrm{PKC} \zeta$ (PKC $\zeta$-KD), and 78 for wild-type $\mathrm{PKC} \zeta(\mathrm{PKC} \zeta-\mathrm{WT})$. For p110 $\gamma$ overexpression, five experiments were quantified, and 40 EGFP-expressing axons and 65 p110 $\gamma$-EGFPexpressing axons were counted. For three $\mathrm{p} 110 \gamma$-KD experiments, a total of 113 EGFP axons and 207 p110 $\gamma$-KD axons were counted.

Electroporation and dissociated commissural neuronal coculture. E13 embryonic spinal cord were electroporated ex utero to the dorsal area with indicated DNA plasmids. Spinal open-book explants were subsequently prepared, and the dorsal domains on the electroporated side were dissected out. The explants then were dissociated as previously described (Augsburger et al., 1999) and plated on poly-D-lysine-laminincoated coverslips. After culturing for $24 \mathrm{~h}$, the progenitors showed differentiated processes, and the neurons in culture were $>90 \%$ Tag- $1+$, conferring commissural identity (supplemental Fig. 1, available at www.jneurosci.org as supplemental material). Electroporated commissural cultures were prepared, plated at a cell density of $\sim 80,000$ progenitor cells $/ 12 \mathrm{~mm}$ coverslip, and incubated for $24 \mathrm{~h}$. COS-7 cells were transfected on the same day with the indicated DNA plasmids and also incubated for $24 \mathrm{~h}$. After neuritic processes could be observed, $2000-$ 4000 transfected COS-7 cells were coplated with the commissural culture on the $12 \mathrm{~mm}$ coverslips. The coculture was allowed to incubate for an additional $24 \mathrm{~h}$ before fixing. Cultures were fixed by the addition of $2 \%$ PFA in culture medium at $37^{\circ} \mathrm{C}$ for $20 \mathrm{~min}$. After fixation, the cultures were stained for EGFP and Myc, and the nucleus was stained with DAPI, and then they were scored for directional and nondirectional growth, as depicted in Figure 5A. The criteria for scoring was that a neuron had only one axon shaft, of at least $50 \mu \mathrm{m}$, and its soma was at a distance of $<200$ $\mu \mathrm{m}$ from a COS-7 cell expressing guidance molecules. We score directional growth by the direction of growth cone navigation relative to the COS-7 cells expressing guidance molecules. Directional growth refers to a neuron whose axon either invaded or grew on a linear path toward the COS-7 cell secreting the guidance molecules, or to an axon that turned approximately within $30^{\circ}$ toward a COS-7 cell expressing the cues; a neuron was determined to be nondirectional if its axon turned from the initial trajectory at an angle $>45^{\circ}$ away from the COS-7 cell secreting the guidance molecules; nondirectional growth also was applied to an axon that ignored and then grew past a COS-7 cell for a distance of $>50 \mu \mathrm{m}$ (the growth beyond COS-7 cell expressing the cues indicates an indifference to the secreted cues). Three trials of each coculture condition were quantified and averaged. Each trial yielded six to eight quantifiable fields of view at $10 \times$ magnification, and each field of view contained two to five neurons that met the scoring criteria for directional or nondirectional growth.

\section{Results $\mathrm{PKC} \zeta$ is required for $\mathrm{A}-\mathrm{P}$ guidance and Wnt4-stimulated outgrowth of commissural axons}

Multiple members of the PKC family of serine/threonine kinases mediate a number of cellular responses. Conventional PKCs require diacylglycerol (DAG) and $\mathrm{Ca}^{2+}$ for activation, novel PKCs require only DAG, and atypical PKCs do not require either DAG or $\mathrm{Ca}^{2+}$ (Kuhl, 2004). To test whether the PKC family plays a role in A-P guidance, we initially used pharmacological inhibitors to block the activities of either all PKCs (GF-109203X; $14 \mu \mathrm{M}$ ) or only conventional PKCs (Gö-6976; $124 \mathrm{nM}$ ) in open-book spinal cord explant assays (Fig. 1A) (Martiny-Baron et al., 1993; Lyuksyutova et al., 2003). In these open-book assays, commissural axons initially grow from the dorsal margin toward the ventral midline and the FP and then cross the midline and make a sharp anterior turn toward the brain. To avoid losing their activity, we added the inhibitors at the approximate time when the first group of dorsal commissural axons reach the midline in our culture (Lyuksyutova et al., 2003). PKC inhibitors were added to the medium $6 \mathrm{~h}$ after initiation of culture. The explants were then cultured in the presence of inhibitors for an additional $14 \mathrm{~h}$ and fixed in 4\% PFA. Axons were visualized by injecting the dorsal spinal cord one-third to one-fourth from the dorsal margin with the fluorescent lipophilic dye DiI (Fig. $1 B$ ). To our surprise, we found that the pan-PKC inhibitor GF-109293X consistently re- 
A

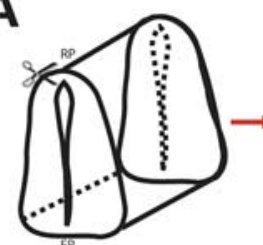

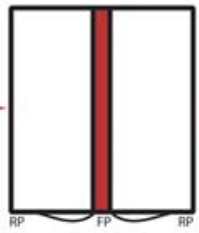

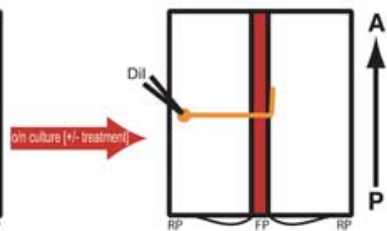

E

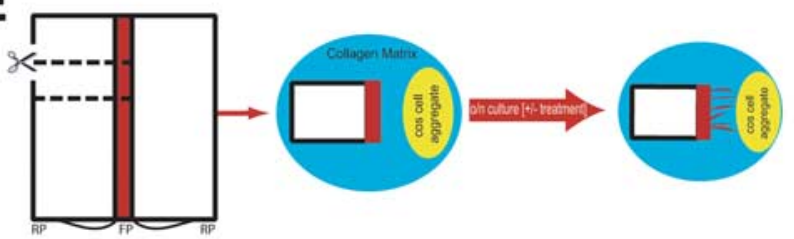

B
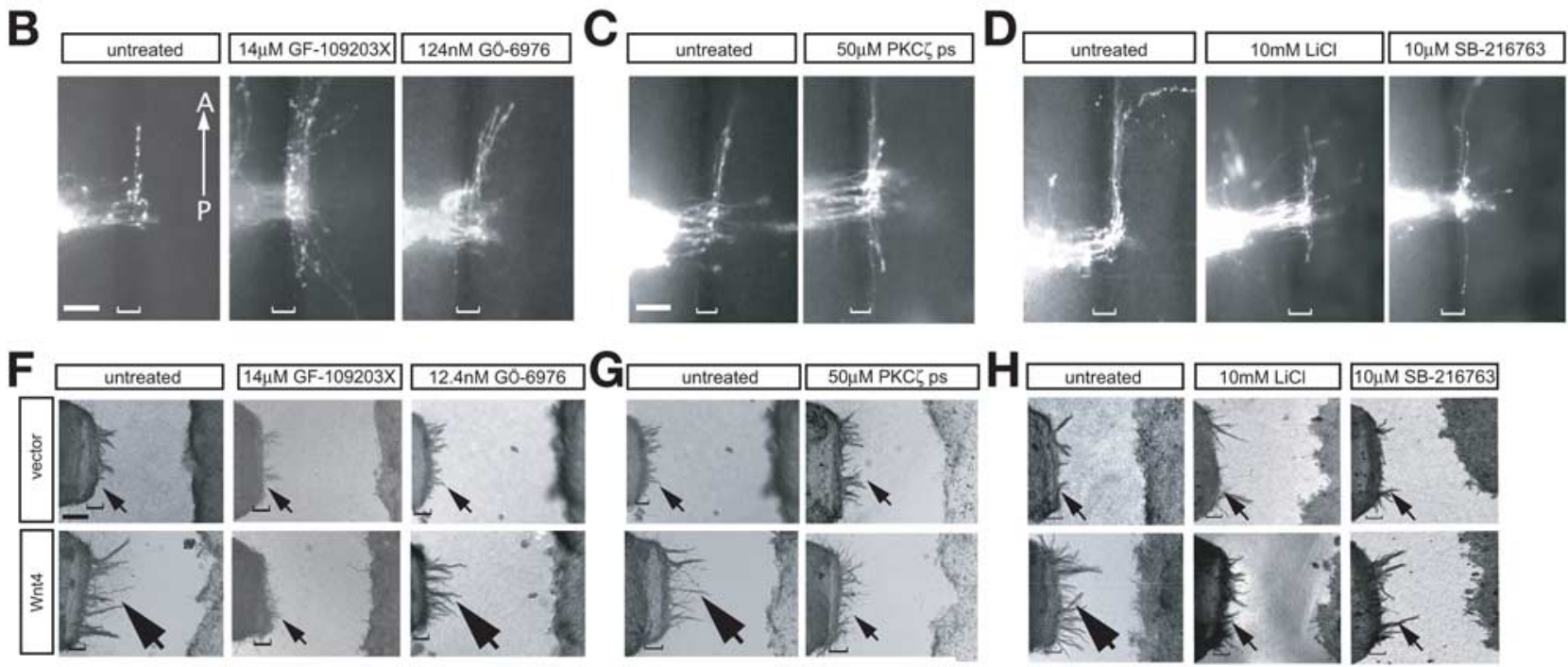

I
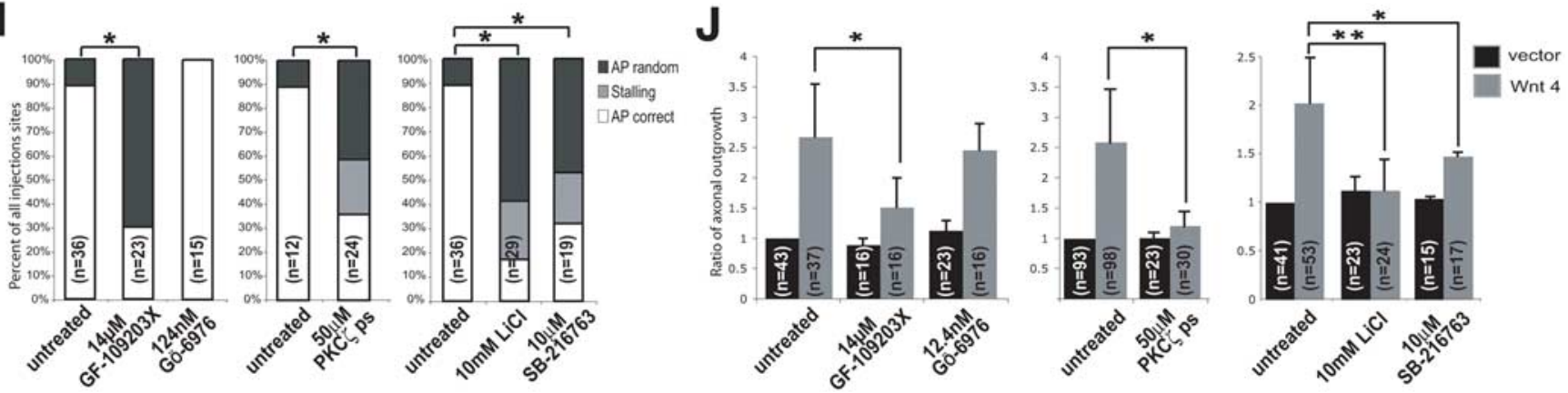

Figure 1. $\quad \mathrm{A} \mathrm{Ca}^{2+}$-independent PKC pathway mediates A-P guidance of commissural axons. $A$, Diagram of the open-book assay from E13 rat spinal cord in collagen gel. RP, Roof plate; $0 / n$, overnight. B, Open-book assays for anterior-posterior pathfinding of commissural axons in the presence of PKC inhibitors GF-109203X and Gö-6976. GF-109203X caused A-P randomization, whereas Gö-6976 did not. C, Open-book assays for anterior turning of commissural axons in the absence and presence of myristoylated PKC $\zeta$ pseudosubstrate (ps). Inhibiting PKC $\zeta$ caused A-P randomization. D, Open-book assays in the absence and presence of inhibitors of GSK-3 $\beta$ inhibitors (LiCl and SB-216763). Inhibiting GSK-3 $\beta$ caused A-P randomization and stalling. E, Diagram of the postcrossing assay. Explants, including floor plate, are dissected and cultured on a matrix of rat-tail collagen. A COS-7 cell aggregate expressing Wnt 4 or vector is placed near the explant and coembedded in collagen. F, G, Postcrossing explant assays for Wnt4-mediated attraction of commissural axons in the presence of PKC inhibitors. The top row is outgrowth in the presence of a control cell aggregate. The bottom row is outgrowth in the presence of a Wnt4-expressing cell aggregate. Arrows mark postcrossing axon outgrowth. $\boldsymbol{H}$, Postcrossing explant assays for Wnt4-mediated attraction of commissural axons in the presence of GSK-3 $\beta$ inhibitors (LiCl and SB-216763). The top row is outgrowth in the presence of a control cell aggregate. The bottom row is outgrowth in the presence of a Wnt4-expressing cell aggregate. Arrows mark postcrossing axon outgrowth. I, Quantification of open-book explant assay experiments. The graph represents the frequency of the axon turning behavior category as a percentage of all injected sites. $n$ is the total number of explants quantified from three separate experiments. ${ }^{*} p<0.005$. J, Quantification of postcrossing assays for Wnt4-mediated attraction in the presence of PKC and GSK3 $\beta$ inhibitors. The graph represents the average total area of outgrowth based on three separate experiments. ${ }^{*} p=0.0347 ;{ }^{* *} p=$ 0.00527. $n$ is the total number of explants quantified. Scale bars, $100 \mu \mathrm{m}$.

sulted in randomization of turning along the A-P axis in postcrossing commissural axons (70.5\% of the injection sites), whereas commissural axons turned anteriorly normally in the presence of the conventional PKC inhibitor Gö-6976 (Fig. 1 B,I). Activation of conventional PKCs requires calcium and diacylglycerol, which are products of PLC activity (Kuhl, 2004). To further test whether conventional PKCs are involved in A-P guidance of commissural axons, we inhibited PLC activity using specific inhibitors U-73122 and neomycin (Carney et al., 1985; Bleasdale et al., 1990). Consistent with our PKC inhibitor observations, inhibition of PLC had no significant effect on A-P guidance of postcrossing commissural axons (data not shown).
To further determine whether the pan-PKC inhibitor (GF109203X) caused A-P randomization by blocking Wnt-mediated axon guidance signaling, we tested whether it could perturb Wnt4-stimulated outgrowth of postcrossing explants (Fig. 1E) (Zou et al., 2000; Lyuksyutova et al., 2003). We found that GF109203X (14 $\mu \mathrm{M})$ blocked Wnt4-stimulated outgrowth, whereas Gö-6976 (12.4 nM), U-73122, and neomycin did not (Fig. 1F, and data not shown). At higher concentration than $12.4 \mathrm{nM}, \mathrm{Gö}-$ 6976 is toxic to axons. Therefore, $12.4 \mathrm{~nm}$ is the highest concentration that can be used in postcrossing assays, whereby axons are more accessible than in open-book assays with larger spinal cord tissues being present. This observation further suggests that the 
calcium/PLC/PKC pathway does not play a significant role in Wnt4-mediated anterior-directed turning, but that a calciumindependent PKC pathway is involved. The concentrations of inhibitors used here are determined empirically because different inhibitors may penetrate tissues and cell membranes at different efficiencies. It is not possible to know the exact concentration of these inhibitors within the growth cones. It should be noted that although these reagents are commonly used to inhibit PKCs, these inhibitors may not be specific to PKCs. Therefore, these results only suggest the potential roles of PKCs in these processes and allowed us to narrow down signaling candidates. We performed subsequent experiments using independent approaches reported later in this paper.

To identify the PKC(s) involved in A-P axon guidance of commissural neurons, we added specific inhibitors of the individual subclasses of PKCs to the open-book explant cultures, including specific PKC pseudosubstrates $(50 \mu \mathrm{M})$, which block PKC activity by preventing binding to their substrates. The pseudosubstrates are myristoylated at the $\mathrm{N}$ terminus to allow cell membrane permeability. We found that the PKC $\zeta$ pseudosubstrate, which blocks atypical PKCs (PKC $\zeta$, and PKC $\lambda / \iota)$ (Gschwendt et al., 1994; Zhou et al., 1997), caused A-P randomization $(41.1 \%)$ of postcrossing commissural axons and stalling $(23.1 \%$ ) (Fig. 1C,I), whereas the PKC $\alpha$ pseudosubstrate, which blocks conventional PKC $\alpha$ and PKC $\beta$ (Eichholtz et al., 1993), had no significant effects (data not shown). To address whether PKC $\zeta$ mediates Wnt4-stimulated outgrowth, we tested these inhibitors in the postcrossing explant assays (Fig. 1G). The presence of PKC $\zeta$ pseudosubstrate $(50 \mu \mathrm{M})$ caused a significant reduction in Wnt4-stimulated outgrowth (Fig. 1G,J) (Baas and Ahmad, 2001), whereas the addition of PKC $\alpha$ pseudosubstrate had no statistically significant effect on postcrossing commissural axons ( $p>0.1$ ), nor did it block the Wnt4-stimulated outgrowth and A-P guidance of postcrossing commissural axons (data not shown). These observations suggest that atypical PKCs are essential signaling components necessary for Wnt4-mediated outgrowth and the A-P turning decision of postcrossing commissural axons.

It has been shown previously that the PKC $\zeta /$ Par6/Par3 complex is required for establishing cell polarity in many cell types, and that GSK $3 \beta$ is directly downstream of the PKC $\zeta / P a r 6 / P a r 3$ complex in this pathway (Etienne-Manneville and Hall, 2003a,b). We tested whether GSK3 $\beta$ is involved in Wntmediated A-P guidance of commissural axons by the addition of the GSK3 $\beta$ inhibitors $\mathrm{LiCl}(10 \mathrm{~mm})$ and SB-216763 $(10 \mu \mathrm{M})$ in the open-book and postcrossing explant assays (Coghlan et al., 2000). We found that both inhibitors caused A-P randomization (LiCl, 59\%; SB-216763, 48\%) and stalling ( $\mathrm{LiCl}, 24 \%$; SB$216763,20.2 \%$ ) of commissural axons after midline crossing (Fig. $1 D, I)$. In addition, these inhibitors reduced Wnt4-stimulated axonal outgrowth in postcrossing explants (Fig. $1 \mathrm{H}, J$ ). These findings are consistent with the observation that inhibition of GSK-3 $\beta$ leads to reduction of neurotrophin-induced axon extension (Krylova et al., 2002).

\section{Phospho-PKC $\zeta$, Par6, and phospho-GSK3 $\beta$ are abundant in the postcrossing axon segment}

To further evaluate the role of $\mathrm{PKC} \zeta$ in vivo, we examined the protein distribution of various signaling components in mouse E11.5 and rat E13 spinal cord, at the time in development when commissural axons are crossing the ventral midline. As shown in the diagram in Figure $2 F$, different segments of the commissural axon tract are visible in transverse spinal cord sections. Precrossing and crossing axons in the midline are visible as long fibers projecting toward the floor plate (blue arrow), whereas postcrossing axon segments are visualized in cross section, presenting as more diffuse staining along the perimeter of the ventral to mid-dorsal spinal cord (green arrow). We found that although $\mathrm{PKC} \zeta$ is broadly expressed in the spinal cord (data not shown), the phosphorylated, activated form of PKC $\zeta(\mathrm{pPKC} \zeta$ ) is abundant in the ventral funiculus, where postcrossing commissural axons are located (Fig. $2 A, A^{\prime}$, arrows), similar to L1, a marker for postcrossing commissural axons (Fig. $2 D$, arrows). In addition, Par6, a key partner of $\mathrm{PKC} \zeta$, is also enriched in the postcrossing segments (Fig. $2 B, B^{\prime}$, arrows). Finally, we found that although GSK $3 \beta$ is broadly expressed throughout the mantle zone of the spinal cord, including the ventral funiculus areas, where postcrossing commissural axons pathfind during this stage of development (data not shown), the phosphorylated form of GSK3 $\beta$ (serine 9) is abundant in postcrossing segments (Fig. $2 C, C^{\prime}$ ). Note that the signals of these components show varied intensity. This may be determined by the antibodies as well as the real quantity of the proteins or phosphoproteins. Nonetheless, we found that these components are present in the commissural axons.

To confirm that the staining represents the protein localization on axons, we performed immunostaining on cryosectioned E13 rat postcrossing explants (Fig. $2 G$ ) and found that pPKC $\zeta$ (Fig. 2A", arrows) and Par6 (Fig. $2 B^{\prime \prime}$, arrows) are indeed abundant on the postcrossing segment of commissural axons that have grown out of the floor plate and entered the collagen gel matrix, similar to L1 (Fig. 2D", arrow). In contrast, TAG-1 was found in the precrossing segment (Fig. 2 E, arrow) but not in the postcrossing segment (Fig. $2 E^{\prime \prime}$, arrowhead) [axons were present as indicated in Fig. $2 E^{\prime \prime}$ (inset, black arrow)]. When we performed the postcrossing assay, one side of the spinal cord tissue was completely removed by making a cut at the border of the floor plate and the ventral spinal cord using a fine tungsten needle, leaving the floor plate still attached to the remaining other side of the spinal cord (Zou et al., 2000). Therefore, all axons emerge from the explants are postcrossing commissural axons. Thus, the components of the pathway described above are present in the right place at the right time during development.

\section{$\mathrm{PKC} \zeta$ kinase activity is required for $\mathrm{A}-\mathrm{P}$ guidance of commissural axons}

To address whether PKC $\zeta$ functions cell autonomously during the anterior turning of commissural axons and confirm the role of PKC $\zeta$ identified by pharmacological inhibition or pseudosubstrate inhibition in mediating $\mathrm{A}-\mathrm{P}$ guidance, we expressed a dominant-negative mutant $\mathrm{PKC} \zeta$ protein in rat dorsal spinal cord open-book explants by electroporation (Fig. $3 A$ ). This technique allows us to introduce DNA into commissural neuron cell bodies, which lie in the dorsal aspect of the spinal cord. Green fluorescent protein under IRES control allows us to visualize all axons expressing the PKC $\zeta$ constructs (Fig. 3 B, C). After electroporation of DNA constructs into the dorsal spinal cord, the spinal cord is opened from the dorsal midline and cultured in a collagen gel matrix. Axons were observed to extend to the midline, cross, and turn normally anteriorly (Fig. $3 C^{\prime}$ ). The GFP signal was present in the entire axons, including the growth cones, allowing us to follow their projections (Fig. $3 C^{\prime \prime}$ ). This K281W mutant (Fig. $3 B$ ) has the critical lysine 281 of the ATP-binding region replaced with tryptophan, resulting in a kinase-defective protein (Romanelli et al., 1999). The kinase-defective PKC $\zeta$ mutant can still be phosphorylated by PDK-1 (phosphoinositide-dependent kinase-1), but it cannot phosphorylate downstream effectors and thus acts as a dominant-negative inhibitor (Romanelli et al., 

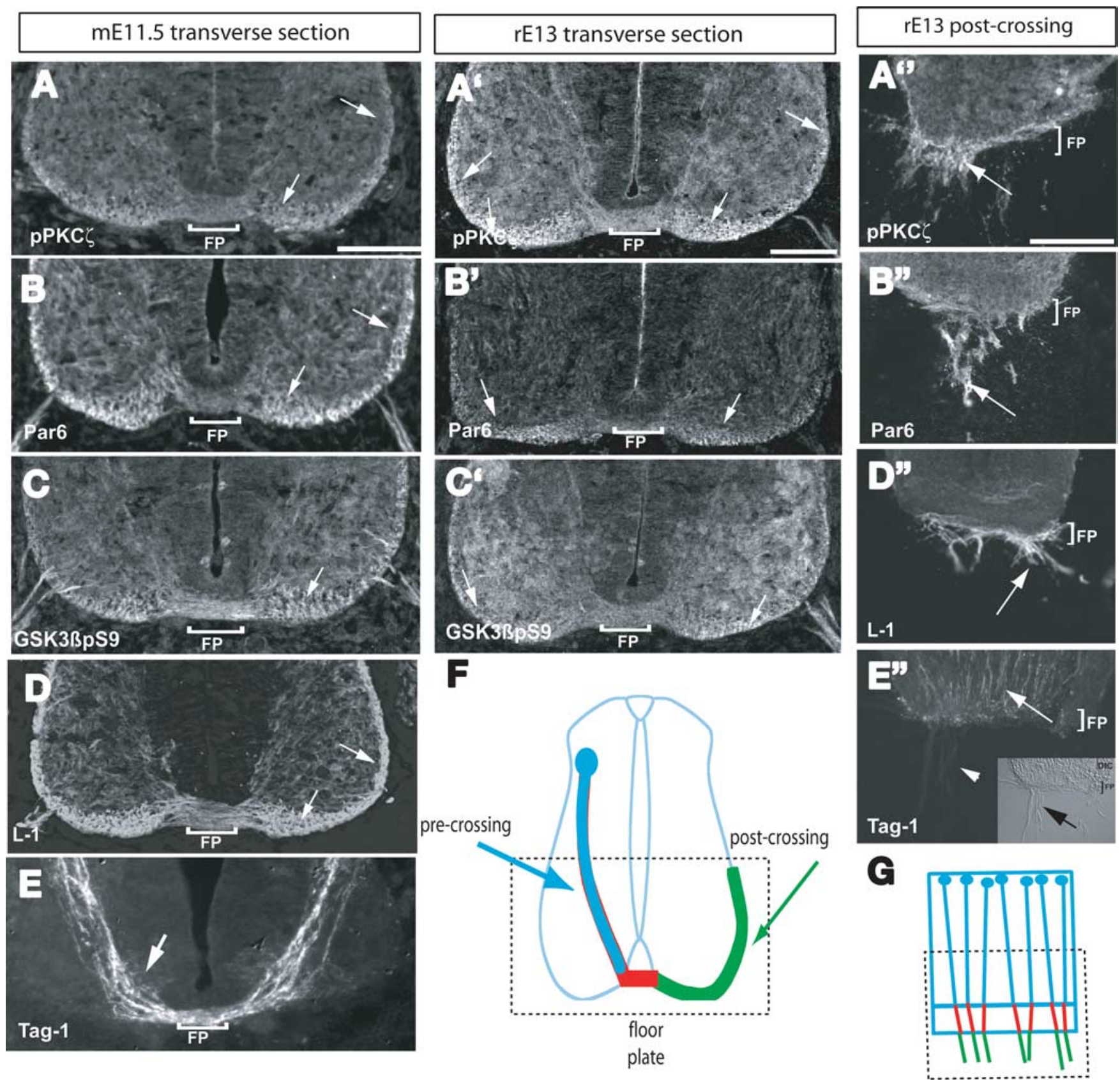

Figure 2. Localization of signaling components necessary for A-P guidance in rat E13 and mouse E11.5 spinal cord. $A-A^{\prime \prime}$, Phosphorylated PKC $\zeta$ in transverse $\left(A_{,} A^{\prime}\right)$ and postcrossing $\left(\boldsymbol{A}^{\prime \prime}\right)$ sections. Arrows indicate immunoreactivity in postcrossing segments. $\boldsymbol{B}-\boldsymbol{B}^{\prime \prime}$, Par6 staining in transverse $\left(\boldsymbol{B}, \boldsymbol{B}^{\prime}\right)$ and postcrossing $\left(\boldsymbol{B}^{\prime \prime}\right)$ sections. Arrows indicate immunoreactivity in postcrossing segments. $\boldsymbol{C}-\boldsymbol{C}^{\prime}$, Phosphorylated GSK3 $\beta(S 9)$ staining in transverse sections. Arrows indicate immunoreactivity in postcrossing segments. $\boldsymbol{D}, \boldsymbol{D}^{\prime \prime}, \mathbf{L} 1$ staining in transverse $(\boldsymbol{D})$ and postcrossing $\left(\boldsymbol{D}^{\prime \prime}\right)$ sections. Arrows indicate postcrossing staining. $\boldsymbol{E} \boldsymbol{E}^{\prime \prime}$, Tag-1 staining in transverse $(\boldsymbol{E})$ and postcrossing $\left(\boldsymbol{E}^{\prime \prime}\right)$ sections. Precrossing staining is present $\left(\boldsymbol{E}, \boldsymbol{E}^{\prime \prime}\right.$, arrows), whereas postcrossing segments are negative ( $\boldsymbol{E}$, arrowhead). Inset, Differential interference contrast image indicates presence of axons (black arrow). $\boldsymbol{F}, \boldsymbol{G}$, Diagrams indicating axon trajectories in transverse $(\boldsymbol{F})$ and postcrossing (G) sections. The precrossing segment is labeled blue, the crossing segment is labeled red, and the postcrossing segment is labeled green. mE11.5, Mouse E11.5; rE13, rat E13.

1999; Etienne-Manneville and Hall, 2001; Hirai and Chida, 2003). We found that this kinase-defective PKC $\zeta$ mutant caused significant A-P randomization after midline crossing, where many axons projected posteriorly after crossing (Fig. $3 D^{\prime \prime}$, arrows) compared with EGFP- or PKC $\zeta$-WT-expressing control axons (Fig. $3 D, D^{\prime}$, arrowheads). In our analyses, we observed that compared with EGFP controls, similar numbers of axons expressing $\mathrm{PKC} \zeta-\mathrm{KD}$ and wild-type constructs reached the midline, suggesting that $\mathrm{PKC} \zeta$ kinase activity is necessary for $\mathrm{A}-\mathrm{P}$ guidance by Wnt attraction after midline crossing but not the precrossing pathfinding (Fig. $3 F$ ). It is also possible that the level of expression achieved by these constructs was not sufficient for precrossing pathfinding (Fig. $3 F$ ). Together, these data suggest that $\mathrm{PKC} \zeta$ functions at least in part cell autonomously in commissural growth cones and is required for $\mathrm{A}-\mathrm{P}$ guidance, a process that requires Wnt-Frizzled signaling.

PI3Ks are required for A-P guidance of commissural axons and may act as an on switch of responsiveness during midline crossing

To address how PKC $\zeta$ may be involved in mediating Wnt attraction, we searched for potential upstream regulators or down- 
A
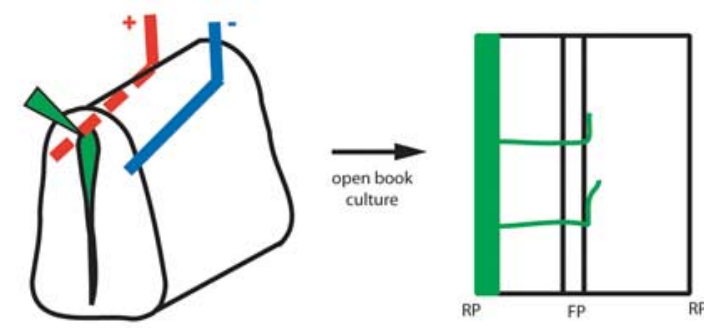

B
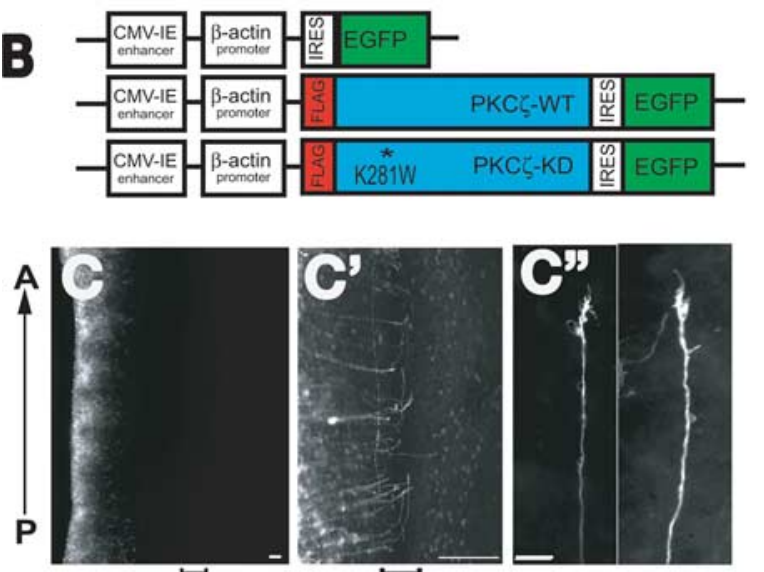

$\overrightarrow{F P}$
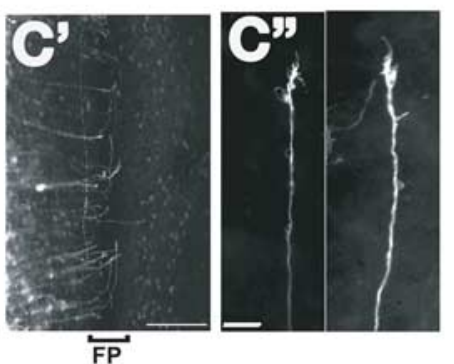
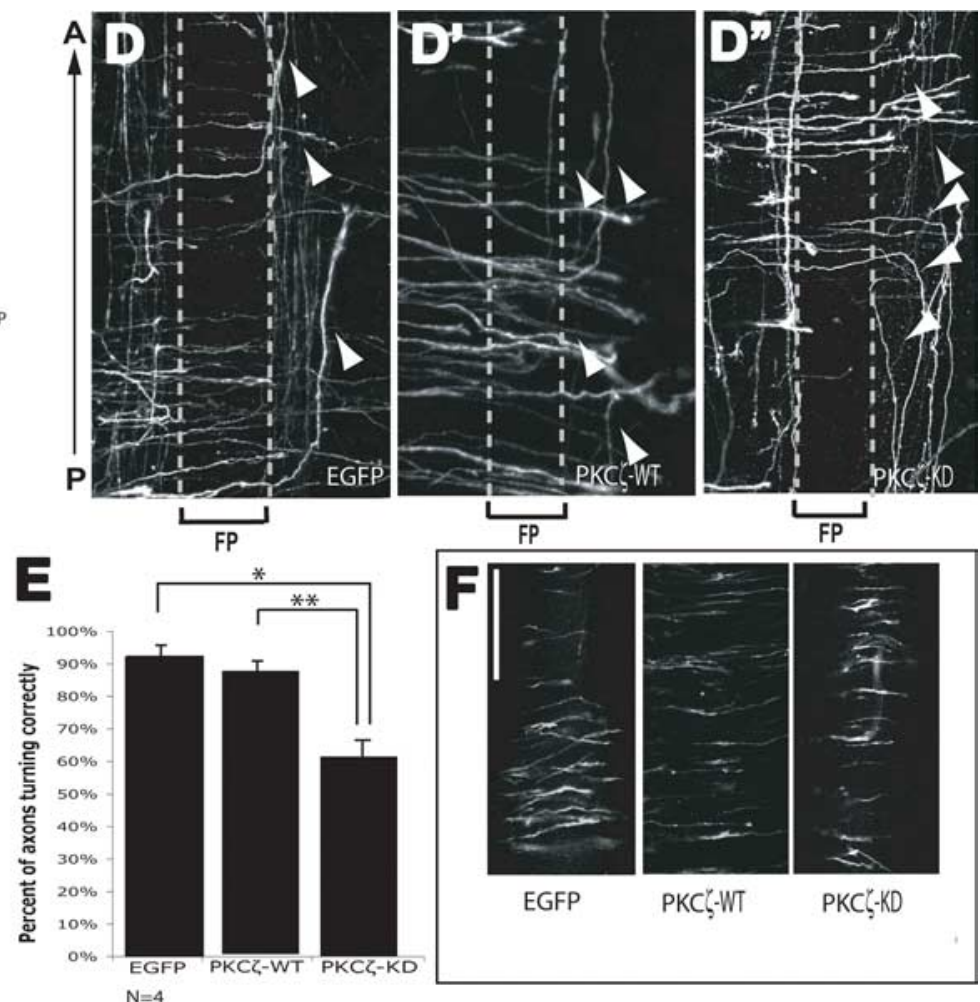

EGFP

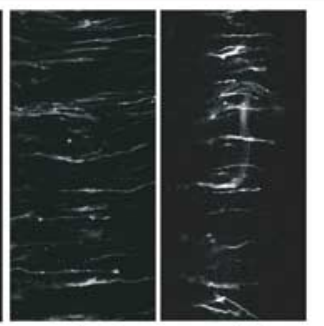

PKC'-WT

Figure 3. PKC $\zeta$ is required in the commissural neuron cell autonomously for A-P guidance at the spinal cord midline. $A$, Diagram of ex utero electroporation. RP, Roof plate. DNA constructs were injected into the central canal of the E13 rat spinal cord, and electroporation targets the dorsal margin of the spinal cord. The spinal cord was then splayed open and cultured in collagen gel. $\boldsymbol{B}$, Schematic of IRES constructs expressed in commissural neurons. The chick $\beta$-actin promoter drives preferential expression in neurons, followed by EGFP, PKC $\zeta$-WT, or PKC $\zeta$-KD. C, As seen in open-book preparation, ex utero electroporation targets commissural cell bodies along the dorsal margin of the spinal cord. $C^{\prime}$, Axons can be visualized approaching and crossing the midline, as well as turning after crossing. $\boldsymbol{C}^{\prime \prime}$, Axon projection can be followed all the way into its longitudinal part. $\mathbf{D}-\boldsymbol{D}^{\prime \prime}$, Open-book assays for commissural axons expressing EGFP or PKC $\zeta$ constructs. $\boldsymbol{D}^{\prime}$, Normal anterior turning of commissural axons expressing wild-type PKC $\zeta$. $\mathbf{D}^{\prime \prime}$, Commissural axons expressing kinase-defective PKC $\zeta$ showed randomized growth along the A-P axis after midline crossing. Arrowheads mark axons turning after crossing, and brackets and dashed lines mark the borders of the FP. E, Quantification of A-P turning in electroporated open-book explants. The graph shows the percentage of axons turning anteriorly. $n$ is the total number of explants quantified from four separate experiments. ${ }^{*} p<0.00005 ;{ }^{* *} p<0.0005 . F$, Similar numbers of commissural axons are observed before midline crossing in explants electroporated with the EGFP, PKC $\zeta$ wild-type, and PKC $\zeta$ kinase-defective constructs. Scale bars, $200 \mu \mathrm{m}$.

stream effectors of atypical PKCs in growth cone guidance. Because Frizzleds are putative GPCRs, we tested whether PTX (800 $\mathrm{ng} / \mathrm{ml}$ ), a $\mathrm{G} \alpha_{\mathrm{i} / \mathrm{o}}$ inhibitor (Ui et al., 1984), can disrupt A-P guidance of commissural axons. We found that addition of PTX resulted in A-P randomization (50\%) (Fig. 4A,B). Previous research has shown that $\mathrm{PKC} \zeta$ can be activated by PI3K signaling (Rickert et al., 2000; Cantley, 2002; Brock et al., 2003). To test whether PI3K is required for Wnt-mediated A-P guidance of commissural axons, we used the open-book assay and found that the general PI3K inhibitor wortmannin $(1 \mu \mathrm{M})$ (Wymann et al., 1996 ) produces A-P randomization (85.5\%) (Fig. 4A, B). These results suggest that heterotrimeric $\mathrm{G}$-proteins and PI3K signaling are required for A-P guidance and may play a role in mediating Wnt attraction.

The PI3K family consists of multiple members (Andrews et al., 2007; Hirsch et al., 2007). Each PI3 kinase has a catalytic domain of $110 \mathrm{kDa}$, named $\mathrm{p} 110$. In addition, a regulatory domain, either p85 or p101, associates with the catalytic domain. $\mathrm{P} 110 \alpha, \beta$, and $\delta$ are known to mediate receptor tyrosine kinase (RTK) signaling in association with p85, whereas $\mathrm{p} 110 \gamma$ has been shown to mediate G-protein-coupled receptor signaling in association with p101. In addition to Frizzleds, other Wnt receptors have been identified, including receptor tyrosine kinase Ror2 (Oishi et al., 2003; Mikels and Nusse, 2006; Nishita et al., 2006). Therefore, all p110s may potentially mediate Wnt responses in axon guidance. We found using reverse transcription (RT)-PCR
(Fig. 4C) and immunohistochemistry (supplemental Fig. 2, available at www.jneurosci.org as supplemental material) that indeed all p110 isoforms are expressed in the embryonic spinal cord and commissural neurons at this stage. Therefore, individual loss of function of p110s may not show any defects as a result of potential redundancy. However, because all PI3Ks catalyze the same reaction, turning PIP2 into PIP3, we hypothesize that a dominant-negative p110 may sufficiently block PI3K signaling. To determine whether PI3K signaling functions cell autonomously for proper A-P guidance of commissural axons, we electroporated a kinase-defective mouse p110 $\gamma$ containing a lysineto-arginine substitution in the ATP binding domain (p110-KD) (Fig. 4D) (Stoyanova et al., 1997; Bondeva et al., 1998). This p $110 \gamma$ mutant protein has been shown to exhibit $0.1 \%$ of the activity of wild-type PI3K $\gamma$ (Wymann et al., 1996). When we introduced this construct (including an IRES-GFP module to label axons that express the dominant-negative construct) into commissural axons, we observed severe guidance errors after midline crossing compared with EGFP electroporated explants (Fig. $4 E, F$ ). Only $60 \%$ of axons projected correctly, compared with $96 \%$ in EGFP electroporated explants $(p<0.005)$ (Fig. $4 G$ ). Most axons showed clear signs of wandering in all directions, and even the few axons that turned anteriorly did not turn sharply as in normal axons (Fig. 4F, arrows). As with the PKC $\zeta$ mutant constructs, axons expressing either p110 $\gamma$-EGFP (translational fusion) or p110 $\gamma$-KD-IRES-EGFP both reached the midline in 
A

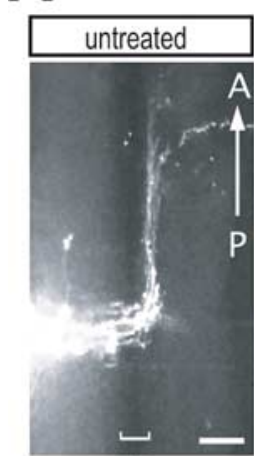

FP

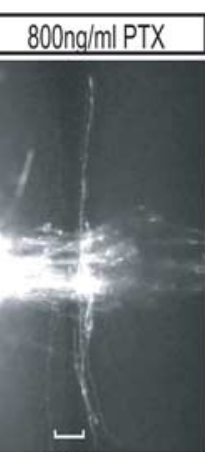

FP

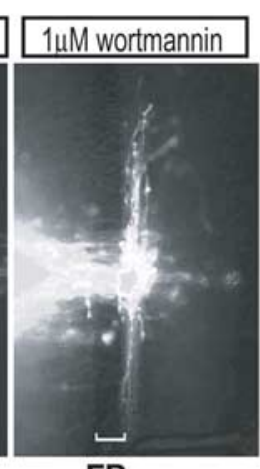

FP
B

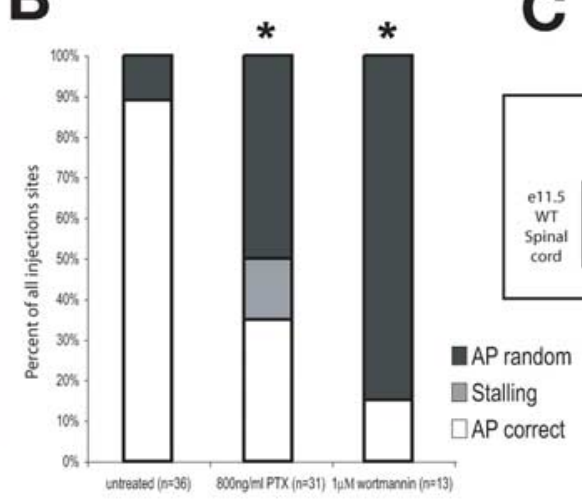

D

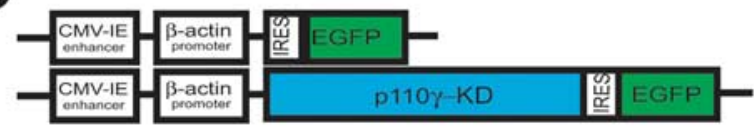

H
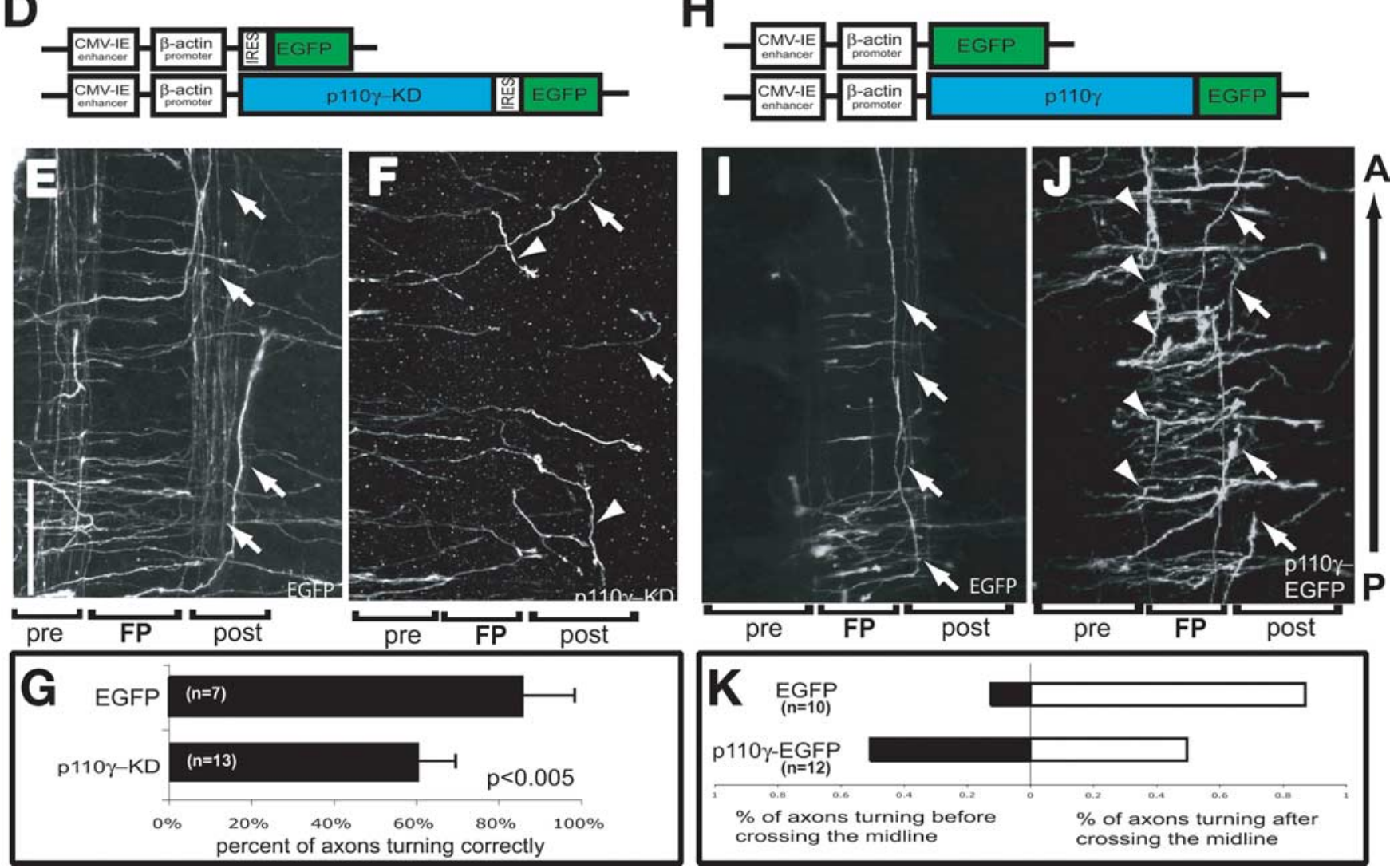

Figure 4. PI3K signaling is required for appropriate anterior-posterior pathfinding of commissural axons. $A, 0$ pen-book explants in the absence or presence of inhibitors of $G \alpha_{\mathrm{i}}$ and $G \alpha_{0}(\mathrm{PTX})$ and PI3K (wortmannin). PTX and wortmannin both caused A-P randomization. $B$, Quantification of open-book explant assay experiments. The graph represents the frequency of the axon turning behavior category as a percentage of all injected sites. $n$ is the total number of explants quantified from three separate experiments. ${ }^{*} p<0.05$. C, Expression of p110 family members in E11.5 spinal cord detected by RT-PCR. D, Schematic of EGFP and p110 $\gamma$-KD IRES EGFP constructs. E, $\boldsymbol{F}$, Open-book assays. $\boldsymbol{E}$, Axons expressing EGFP. Arrows indicate anterior directed axons. $\boldsymbol{F}$, Axons expressing p110 $\gamma$-KD. Commissural axons wander in all directions after midline crossing. The anterior-turning axons (arrows) turned in wide angles instead of in the normal $90^{\circ}$ sharp angles. Arrows indicate anterior-directed axons, and arrowheads indicate posterior-directed axons. G, Quantification of A-P turning in open-book assays with p110 $\gamma$-KD electroporation. Approximately $65 \%$ of axons turned correctly when expressing the kinase-defective construct, as opposed to $96 \%$ of EGFP-expressing axons. $n$ indicates the number of explants. $\boldsymbol{H}$, Schematic of EGFP and p110 $\gamma$-EGFP fusion constructs. I, J, Open-book assays. I, Navigation of axons expressing EGFP protein. Arrows indicate anterior directed axons. J, Axons expressing p110 $\gamma$-EGFP. Arrows indicate axons turning anteriorly after midline crossing. Arrowheads indicate axons turning anteriorly before midline crossing. $\boldsymbol{K}$, Quantification of anterior turning before and after crossing. Approximately $50 \%$ of the axons turned anteriorly before midline crossing when p110 $\gamma$-EGFP fusion protein was expressed. $n$ indicates the number of explants. Scale bars, $100 \mu \mathrm{m}$.

numbers comparable with those of EGFP-expressing axons, indicating that expression of this construct did not disrupt precrossing pathfinding (data not shown).

To our surprise, when we overexpressed p $110 \gamma$-WT fused to EGFP in commissural axons in an open-book preparation (Fig. $4 J, K$ ), we found that many commissural axons, which usually only turn anteriorly after midline crossing (Fig. 4I, arrows), now turned anteriorly before midline crossing (Fig. $4 \mathrm{~J}$, arrowheads), suggesting that the overexpression of $\mathrm{p} 110 \gamma$ changed the responsiveness of commissural axon growth cones at the midline. Approximately $50 \%$ of the axons expressing p110 $\gamma$-WT (Fig. $4 \mathrm{~J}, \mathrm{~K}$ ) turned anteriorly before midline crossing, compared with $10 \%$ of axons expressing GFP in the open-book culture (Fig. $4 I, K$ ). We also noticed that the pathfinding of commissural axons of both the precrossing and postcrossing longitudinal tracts expressing p110 $\gamma$-WT remained correct (data not shown). In our electropo- 
A

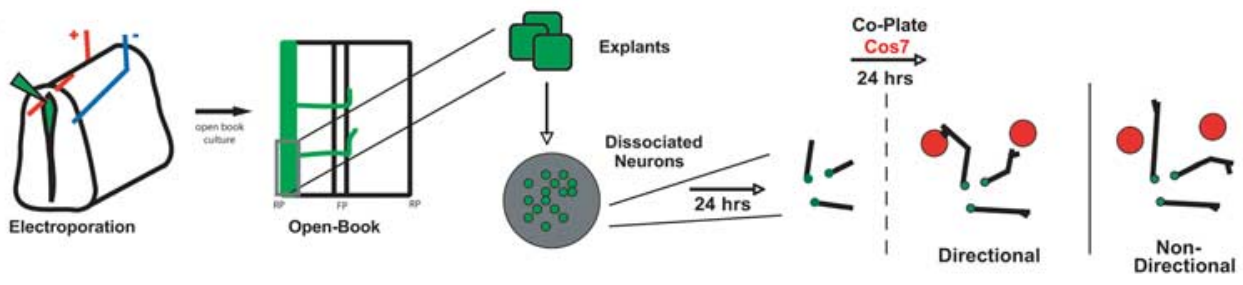

B

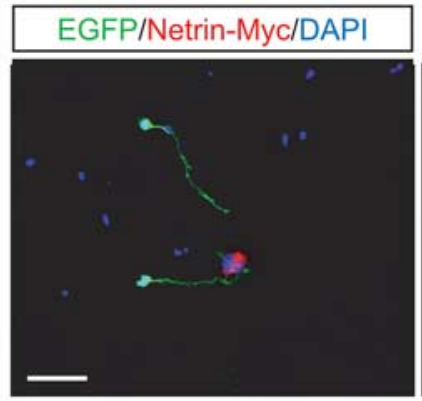

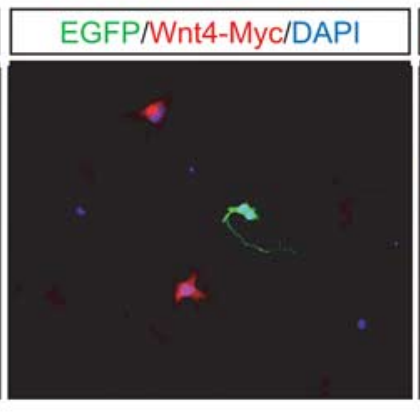

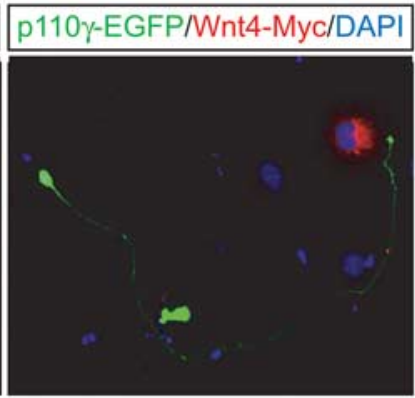

C

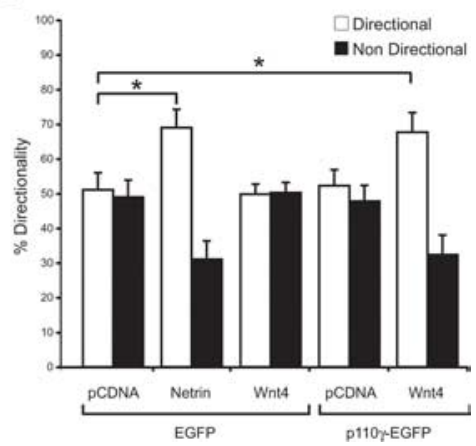

Figure 5. Wnt 4 attracts P110 $\gamma$-EGFP-expressing commissural axons. $A$, Diagram of the coculture assay of dissociated spinal cord neurons and COS cells expressing guidance cues. Neurons with only one axon shaft of at least $50 \mu \mathrm{m}$ and their somata at a distance of $<200 \mu \mathrm{m}$ from a COS-7 cell expressing guidance molecules were scored. Directional growth was scored by the direction of growth cone navigation relative to the COS-7 cells expressing guidance molecules. Directional growth refers to a neuron whose axon either invaded or grew on a linear path toward the COS-7 cell secreting the guidance molecules, or to an axon that turned approximately within $30^{\circ}$ toward a COS-7 expressing the cues; nondirectional refers to an axon that turned from the initial trajectory at an angle $>45^{\circ}$ away from the COS-7 cell secreting the guidance molecules or an axon that grew parallel to and then past a COS-7 cell for a distance of $>50 \mu \mathrm{m}$. RP, Roof plate. $\boldsymbol{B}$, Left, Commissural axons expressing EGFP grow directionally toward Netrin-1-expressing COS-7 cells. Middle, EGFP-expressing axons growing nondirectionally, indicating that precrossing axons are not yet sensitized to Wnt4-expressing COS-7 cells. However, after P110 $\gamma$-EGFP overexpression, commissural axons respond to the Wnt4-expressing cells and grow directionally toward them. C, Quantification of the coculture assay. P110 $\gamma$-EGFP expression results in directional growth to Wnt4. ${ }^{*} p<0.02$. Scale bar, $50 \mu \mathrm{m}$.

ration experiments, we sometimes observed axons that did not turn at all, but projected toward the dorsal margin of the contralateral spinal cord. These projections have been described previously (Kadison and Kaprielian, 2004), and we did not observe any obvious differences in the frequency or behavior of these axons between our control and experimental conditions.

\section{P110 $\gamma$ overexpression caused dissociated precrossing commissural axons to respond to Wnt4 attraction} It has been shown previously that the catalytic domain of PI3K alone can act as a constitutively active form (Lopez-Ilasaca et al., 1997; Kang et al., 2006). Several guidance cues regulate the pathfinding behavior at the midline. The precocious anterior turning of commissural axons before crossing may be caused by switching on responsiveness to Wnt attraction or to midline repellents, such as Slits and Sema3B (Zou et al., 2000; Long et al., 2004). To address whether PI3K can sensitize Wnt attraction, we performed dissociated commissural neuronal cultures from dorsal spinal cords electroporated with the p110 $\gamma$-WT overexpression construct (Fig. 5A). These commissural neuron progenitors have not grown axons, and their axons have not encountered the midline. They were cocultured with COS cells transfected with Netrin-1 or Wnt4, which were detected by immunostaining with an anti-myc antibody because both Netrin-1 and Wnt4 are myc tagged (Fig. $5 B$, red). We found that commissural neurons expressing only the EGFP marker were attracted to COS cells expressing Netrin-1 but not to those expressing Wnt4. Overexpression of p110 $\gamma$ EGFP fusion protein caused these axons to respond to Wnt4 attraction (Fig. $5 B, C$ ). As shown in Figure 5, $B$ and $C, 69.0 \%$ of precrossing commissural neurons grew directionally, and $31.0 \%$ grew nondirectionally toward Netrin-1-expressing COS cells, whereas the percentage of directional and nondirectional growth toward Wnt4 remained essentially the same $(49.8 \%$ and $50.2 \%$, respectively), indicating that precrossing axons are not yet sensitized to Wnt4. Similar values were obtained with pCDNAtransfected COS cell controls (51.0\% directional and 49.0\% nondirectional growth for EGFP axons, 52.3\% directional and $47.7 \%$ nondirectional growth for p110 $\gamma$-EGFP-expressing axons). However, overexpression of p110 $\gamma$-EGFP fusion caused these axons to respond to Wnt4 (Fig. $5 B$ ). Of the axons overexpressing p110 $\gamma$-EGFP, $67.6 \%$ grew directionally and $32.4 \%$ nondirectionally toward Wnt4-expressing COS cells, which is similar to the responsiveness of precrossing commissural axons marked by EGFP to COS cells expressing Netrin-1. Therefore, the precocious anterior turning of commissural axons in the open-book assay (Fig. $4 J, K$ ) is in part attributable to the activation of Wnt attraction.

\section{Discussion}

Wnt signaling and anterior-posterior axon guidance at the CNS midline

Wnt signaling is a highly conserved mechanism for axon guidance along the anterior-posterior axis. Studies in vertebrates have suggested that multiple classes of axons project along the anterior-posterior axis (Lyuksyutova et al., 2003; Liu et al., 2005). Mutations in the Wnt and Frizzled genes also cause anterior-posterior guidance defects in Caenorhabditis elegans (Hilliard and Bargmann, 2006; Pan et al., 2006; Prasad and Clark, 2006). In vertebrate spinal cord, a rostral-to-caudal decreasing gradient of several Wnt genes, particularly Wnt4 and Wnt7b, was observed in the midline glial cells and the floor plate cells. The commissural axons originate from the dorsal spinal cord, are initially attracted to the floor plate, and grow toward the ventral midline, which secretes chemoattractants, Netrin-1 and Sonic Hedgehog. After 
midline crossing, they lose attraction to the floor plate and gain responsiveness to chemorepellents, the Slits and Semaphorins, which turn their direction of growth from dorsal-ventral to the anterior-posterior axis. The anterior turning of these commissural axons depends on Wnt-Frizzled signaling (Lyuksyutova et al., 2003). The midline is a major organizer of the pathfinding of the commissural axons, directing the growth along both the dorsal-ventral and anterior-posterior axes. This study explores the signaling mechanisms mediating the anterior-posterior guidance function of the Wnt family guidance molecules.

\section{Atypical PKC mediates Wnt signaling in axon guidance}

Wnt proteins have recently been implicated in axon guidance in a number of species, yet the intracellular mechanisms that mediate Wnt signaling in axon guidance have not been unveiled. Here we report that atypical PKC signaling is necessary for the anteriorposterior guidance and Wnt-mediated attraction of spinal cord commissural axons.

Atypical PKC is an essential component in a signaling complex involved establishing cell polarity in both invertebrates and vertebrates, from partitioning cytoplasmic determinants in early C. elegans embryos to apical-basal (A/B) cell polarization in Drosophila and vertebrate epithelia (Karner et al., 2006). This highly conserved polarity signaling complex, including founding members called Par proteins and several other proteins, such as lethal giant larvae ( $\mathrm{Lgl}$ ), the Crb (crumbs) complex, and the Scrb (scribble) complex, has been recently implicated in neuronal polarity development, determining axon-dendrite differentiation (Joberty et al., 2000; Lin, 2000; Etienne-Manneville and Hall, 2003b; Henrique and Schweisguth, 2003; Shi et al., 2003; Nishimura, 2004). Studies suggest complex interactions between Wnt signaling and the A/B polarity signaling pathways (Karner et al., 2006). On one hand, A/B polarity signaling influences Wnt signaling. Par1 potentiates canonical Wnt signaling and inhibits noncanonical signaling (Sun et al., 2001; Ossipova et al., 2005). LKB1 (Par4) inhibits GSK-3 $\beta$ and promotes canonical signaling via the function of Par6/aPKC complex, which is downstream of Cdc42 (Etienne-Manneville and Hall, 2003a; Ossipova et al., 2003). LKB1 can also inhibit canonical Wnt signaling by phosphorylated Parl and inactivates its function (Spicer et al., 2003; Lizcano et al., 2004). On the other hand, Wnt signaling can directly affect A/B polarity. Dishevelled and Frizzled directly regulate the localization of Lgl (Dollar et al., 2005). Some of the components of $\mathrm{A} / \mathrm{B}$ polarity signaling pathway are transcriptional targets of canonical Wnt signaling (Tao et al., 2001; Malliri et al., 2006). Therefore, Wnt signaling can act upstream of the $A / B$ polarity signaling as well. Our work provides further support for that notion. We show here that aPKC signaling (not Wnt canonical signaling) is required for Wnt-mediated attraction. This is consistent with the finding that the downstream components of the PAR3/PAR6/aPKC pathway, such as GSK-3 $\beta$, are also important regulators of axon growth (Zhou et al., 2004). Moreover, during the course of our work, Zhang et al. (2007) showed that Wnts regulate the level of $\mathrm{PKC} \zeta$ via its interaction with Dishevelled during the establishment of neuronal polarity in cultured hippocampal neurons. Together with our work in anterior turning of commissural axons, we propose that a similar molecular signaling network that controls cell polarity is used here during growth cone guidance. Further studies will delineate the function of the various A/B polarity complex components in growth cone guidance.

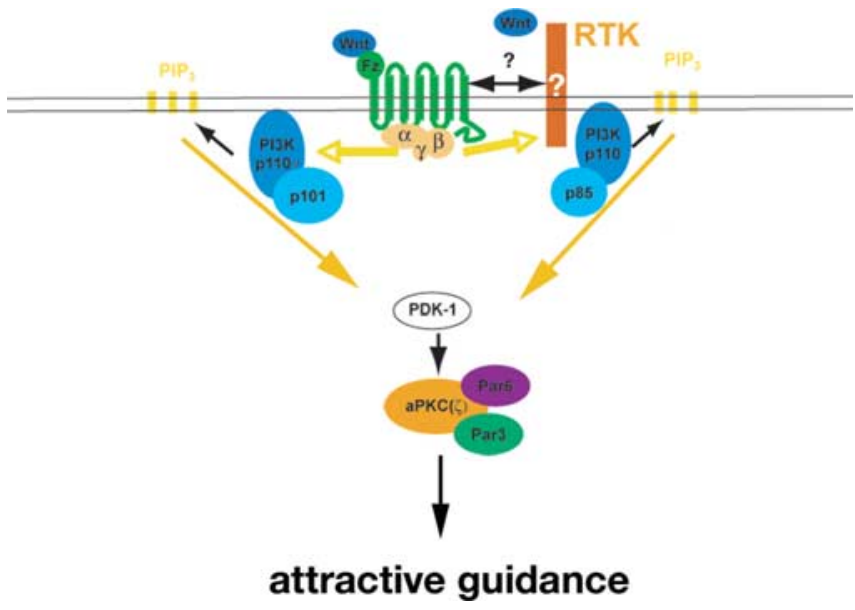

Figure 6. Diagram of a PI3 kinase-aPKC signaling pathway mediating Wnt attraction in axon guidance. PDK-1, Phosphoinositide-dependent kinase-1.

\section{Phosphoinositides and Wnt signaling}

Phosphoinositides are an important upstream regulator of $\mathrm{PKC} \zeta$ signaling. PI3Ks can be activated by both receptor tyrosine kinases and G-protein-coupled receptors (Soltoff et al., 1992; Sasaki et al., 2000). A more recently identified Wnt receptor, Ror2, is an RTK (Oishi et al., 2003; Mikels and Nusse, 2006; Nishita et al., 2006), and Frizzleds have also been shown to be GPCRs (Malbon, 2004). In addition, transactivation of RTK by GPCRs can occur as well (Lee et al., 2002). Our results with pertussis toxin suggest that heterotrimeric G-proteins (probably $\mathrm{G} \alpha_{\mathrm{i} / \mathrm{o}}$ ) are required for A-P axon guidance. Therefore, we propose that multiple members of the PI3Ks are likely involved in mediating Wnt signaling to activate PKC $\zeta$ (Fig. 6). Indeed, all members of the p110 family (the catalytic domains of the PI3Ks) are present in commissural neurons (data not shown). We analyzed the p110 $\gamma$ knock-out mice and found that anterior-posterior guidance of commissural axons is not affected (data not shown). This is likely attributable to the high levels of redundancy of p110 family function. However, a dominant-negative form of p110 $\gamma$ (kinase-dead), which should presumably block all PI3 kinase signaling (producing PIP3 from PIP2), caused major guidance defects after midline crossing, highlighting the function of $\mathrm{PI} 3 \mathrm{~K}$ s during A-P pathfinding. Because pertussis toxin produced an A-P guidance defect, we think that the PI3Ks that are dependent on RTKs also rely on heterotrimeric G-proteins, requiring the GPCR function of Frizzleds either in a complex or through transactivation (Lee et al., 2002). Future work will be necessary to sort out the exact mechanisms of action. Our work suggests a novel link between Wnt signaling and PI3K signaling. The PI3K/ $\mathrm{PKC} \zeta$ signaling module is also involved in mediating other signaling pathways, possibly other guidance systems. This study shows its requirement in Wnt signaling, and future studies will explore the possibility of signaling convergence of Wnts and other guidance or modulating factors through this signaling module.

\section{PI3K signaling as a switch of growth cone responsiveness at the midline}

A fundamental mechanism of complex neuronal network wiring is the usage of intermediate targets or guideposts. Highly complex axonal networks can be created by switching the growth cone's responsiveness to cues present at or around the intermediate targets. The midline has served as a wonderful model system to 
study changes in responsiveness at intermediate targets. Several models, which are not mutually exclusive, have been proposed, including hierarchical ordering among guidance systems (Stein and Tessier-Lavigne, 2001), local translational control (Brittis et al., 2002), and receptor sorting (Keleman et al., 2002). We show that overexpression of a catalytic subunit, p1 $10 \gamma$, switched on the attractive responsiveness to $\mathrm{Wnt} 4$, and commissural axons turned anteriorly before midline crossing. PI3Ks are known to be able to regulate the sensitivity of growth cone signaling functions, such as Semaphorins (Eickholt et al., 2007). We show here that they also regulate $\mathrm{W} n t$ responsiveness at the midline of the spinal cord.

Growth cone turning requires coordinated intracellular events involving changes in actin dynamics, microtubule cytoskeleton organization, and membrane trafficking. These processes are highly choreographed in pathfinding growth cones. It is likely that multiple signaling pathways are required to regulate these different aspects of subcellular changes to allow growth cones to make directional turns. Identification of this PI3K $\gamma$ PKC $\zeta$ pathway does not exclude other pathways, such as the PCP pathway, for orchestrating different aspects of this cellular process (Logan and Nusse, 2004; Zou, 2004). For example, downstream effectors of $\mathrm{PKC} \zeta$ appear to directly or indirectly regulate microtubules. PCP signaling can potentially influence both actin cytoskeleton (via RhoA) and microtubules (via JNK) in axon guidance. A coherent picture of the process of growth cone guidance will emerge when the roles of each of these signaling pathways are understood within the cellular context of navigating growth cones.

\section{References}

Andrews S, Stephens LR, Hawkins PT (2007) PI3K class IB pathway in neutrophils. Sci STKE 2007:cm3.

Augsburger A, Schuchardt A, Hoskins S, Dodd J, Butler S (1999) BMPs as mediators of roof plate repulsion of commissural neurons. Neuron 24:127-141.

Baas PW, Ahmad FJ (2001) Force generation by cytoskeletal motor proteins as a regulator of axonal elongation and retraction. Trends Cell Biol 11:244-249.

Bleasdale JE, Thakur NR, Gremban RS, Bundy GL, Fitzpatrick FA, Smith RJ, Bunting S (1990) Selective inhibition of receptor-coupled phospholipase C-dependent processes in human platelets and polymorphonuclear neutrophils. J Pharmacol Exp Ther 255:756-768.

Bondeva T, Pirola L, Bulgarelli-Leva G, Rubio I, Wetzker R, Wymann MP (1998) Bifurcation of lipid and protein kinase signals of PI3Kgamma to the protein kinases PKB and MAPK. Science 282:293-296.

Brittis PA, Lu Q, Flanagan JG (2002) Axonal protein synthesis provides a mechanism for localized regulation at an intermediate target. Cell 110:223-235.

Brock C, Schaefer M, Reusch HP, Czupalla C, Michalke M, Spicher K, Schultz G, Nurnberg B (2003) Roles of G beta gamma in membrane recruitment and activation of p110 gamma/p101 phosphoinositide 3-kinase gamma. J Cell Biol 160:89-99.

Cantley LC (2002) The phosphoinositide 3-kinase pathway. Science 296:1655-1657.

Carney DH, Scott DL, Gordon EA, LaBelle EF (1985) Phosphoinositides in mitogenesis: neomycin inhibits thrombin-stimulated phosphoinositide turnover and initiation of cell proliferation. Cell 42:479-488.

Ciani L, Salinas PC (2005) WNTs in the vertebrate nervous system: from patterning to neuronal connectivity. Nat Rev Neurosci 6:351-362.

Coghlan MP, Culbert AA, Cross DA, Corcoran SL, Yates JW, Pearce NJ, Rausch OL, Murphy GJ, Carter PS, Roxbee Cox L, Mills D, Brown MJ, Haigh D, Ward RW, Smith DG, Murray KJ, Reith AD, Holder JC (2000) Selective small molecule inhibitors of glycogen synthase kinase-3 modulate glycogen metabolism and gene transcription. Chem Biol 7:793-803.

Cohen ED, Mariol MC, Wallace RM, Weyers J, Kamberov YG, Pradel J, Wilder EL (2002) DWnt4 regulates cell movement and focal adhesion kinase during Drosophila ovarian morphogenesis. Dev Cell 2:437-448.
Dollar GL, Weber U, Mlodzik M, Sokol SY (2005) Regulation of Lethal giant larvae by Dishevelled. Nature 437:1376-1380.

Eichholtz T, de Bont DB, de Widt J, Liskamp RM, Ploegh HL (1993) A myristoylated pseudosubstrate peptide, a novel protein kinase $\mathrm{C}$ inhibitor. J Biol Chem 268:1982-1986.

Eickholt BJ, Ahmed AI, Davies M, Papakonstanti EA, Pearce W, Starkey ML, Bilancio A, Need AC, Smith AJ, Hall SM, Hamers FP, Giese KP, Bradbury EJ, Vanhaesebroeck B (2007) Control of axonal growth and regeneration of sensory neurons by the p110delta PI 3-kinase. PLoS ONE 2:e869.

Etienne-Manneville S, Hall A (2001) Integrin-mediated activation of Cdc42 controls cell polarity in migrating astrocytes through PKCzeta. Cell 106:489-498.

Etienne-Manneville S, Hall A (2003a) Cdc42 regulates GSK-3beta and adenomatous polyposis coli to control cell polarity. Nature 421:753-756.

Etienne-Manneville S, Hall A (2003b) Cell polarity: Par6, aPKC and cytoskeletal crosstalk. Curr Opin Cell Biol 15:67-72.

Fradkin LG, Garriga G, Salinas PC, Thomas JB, Yu X, Zou Y (2005) Wnt signaling in neural circuit development. J Neurosci 25:10376-10378.

Gschwendt M, Muller HJ, Kielbassa K, Zang R, Kittstein W, Rincke G, Marks F (1994) Rottlerin, a novel protein kinase inhibitor. Biochem Biophys Res Commun 199:93-98.

HeX, Semenov M, Tamai K, Zeng X (2004) LDL receptor-related proteins 5 and 6 in Wnt/beta-catenin signaling: arrows point the way. Development 131:1663-1677.

Henrique D, Schweisguth F (2003) Cell polarity: the ups and downs of the Par6/aPKC complex. Curr Opin Genet Dev 13:341-350.

Hilliard MA, Bargmann CI (2006) Wnt signals and Frizzled activity orient anterior-posterior axon outgrowth in C. elegans. Dev Cell 10:379-390.

Hirai T, Chida K (2003) Protein kinase Czeta (PKCzeta): activation mechanisms and cellular functions. J Biochem (Tokyo) 133:1-7.

Hirsch E, Costa C, Ciraolo E (2007) Phosphoinositide 3-kinases as a common platform for multi-hormone signaling. J Endocrinol 194:243-256.

Joberty G, Petersen C, Gao L, Macara IG (2000) The cell-polarity protein Par6 links Par3 and atypical protein kinase C to Cdc42. Nat Cell Biol 2:531-539.

Kadison SR, Kaprielian Z (2004) Diversity of contralateral commissural projections in the embryonic rodent spinal cord. J Comp Neurol 472:411-422.

Kang S, Denley A, Vanhaesebroeck B, Vogt PK (2006) Oncogenic transformation induced by the p110beta, -gamma, and -delta isoforms of class I phosphoinositide 3-kinase. Proc Natl Acad Sci USA 103:1289-1294.

Karner C, Wharton KA, Carroll TJ (2006) Apical-basal polarity, Wnt signaling and vertebrate organogenesis. Semin Cell Dev Biol 17:214-222.

Keleman K, Rajagopalan S, Cleppien D, Teis D, Paiha K, Huber LA, Technau GM, Dickson BJ (2002) Comm sorts robo to control axon guidance at the Drosophila midline. Cell 110:415-427.

Krylova O, Herreros J, Cleverley KE, Ehler E, Henriquez JP, Hughes SM, Salinas PC (2002) WNT-3, expressed by motoneurons, regulates terminal arborization of neurotrophin-3-responsive spinal sensory neurons. Neuron 35:1043-1056.

Kuhl M (2004) The WNT/calcium pathway: biochemical mediators, tools and future requirements. Front Biosci 9:967-974.

Lee FS, Rajagopal R, Chao MV (2002) Distinctive features of Trk neurotrophin receptor transactivation by $\mathrm{G}$ protein-coupled receptors. Cytokine Growth Factor Rev 13:11-17.

Lin D (2000) A mammalian PAR-3-PAR-6 complex implicated in Cdc42/ Rac1 and aPKC signaling and cell polarity. Nat Cell Biol 2:540-547.

Liu Y, Shi J, Lu C-C, Wang Z-B, Lyuksyutova AI, Song X, Zou Y (2005) Ryk-mediated Wnt repulsion regulates posterior-directed growth of corticospinal tract. Nat Neurosci 8:1151-1159.

Lizcano JM, Goransson O, Toth R, Deak M, Morrice NA, Boudeau J, Hawley SA, Udd L, Makela TP, Hardie DG, Alessi DR (2004) LKB1 is a master kinase that activates 13 kinases of the AMPK subfamily, including MARK/ PAR-1. EMBO J 23:833-843.

Logan CY, Nusse R (2004) The Wnt signaling pathway in development and disease. Annu Rev Cell Dev Biol 20:781-810.

Long H, Sabatier C, Ma L, Plump A, Yuan W, Ornitz DM, Tamada A, Murakami F, Goodman CS, Tessier-Lavigne M (2004) Conserved roles for Slit and Robo proteins in midline commissural axon guidance. Neuron 42:213-223.

Lopez-Ilasaca M, Li W, Uren A, Yu JC, Kazlauskas A, Gutkind JS, Heidaran 
MA (1997) Requirement of phosphatidylinositol-3 kinase for activation of JNK/SAPKs by PDGF. Biochem Biophys Res Commun 232:273-277.

Lu W, Yamamoto V, Ortega B, Baltimore D (2004) Mammalian Ryk is a Wnt coreceptor required for stimulation of neurite outgrowth. Cell 119:97-108.

Lyuksyutova AI, Lu CC, Milanesio N, King LA, Guo N, Wang Y, Nathans J, Tessier-Lavigne M, Zou Y (2003) Anterior-posterior guidance of commissural axons by Wnt-frizzled signaling. Science 302:1984-1988.

Malbon CC (2004) Frizzleds: new members of the superfamily of G-protein-coupled receptors. Front Biosci 9:1048-1058.

Malliri A, Rygiel TP, van der Kammen RA, Song JY, Engers R, Hurlstone AF, Clevers H, Collard JG (2006) The rac activator Tiam1 is a Wntresponsive gene that modifies intestinal tumor development. J Biol Chem 281:543-548.

Martiny-Baron G, Kazanietz MG, Mischak H, Blumberg PM, Kochs G, Hug H, Marme D, Schachtele C (1993) Selective inhibition of protein kinase C isozymes by the indolocarbazole Go 6976. J Biol Chem 268:9194-9197.

Mikels AJ, Nusse R (2006) Purified Wnt5a protein activates or inhibits betacatenin-TCF signaling depending on receptor context. PLoS Biol 4:e115.

Nishimura T (2004) Role of the PAR-3-KIF3 complex in the establishment of neuronal polarity. Nat Cell Biol 6:328-334.

Nishimura T, Yamaguchi T, Kato K, Yoshizawa M, Nabeshima Y-i, Ohno S, Hoshino M, Kaibuchi K (2005) PAR-6-PAR-3 mediates Cdc42-induced Rac activation through the Rac GEFs STEF/Tiam1. Nat Cell Biol $7: 270-277$

Nishita M, Yoo SK, Nomachi A, Kani S, Sougawa N, Ohta Y, Takada S, Kikuchi A, Minami Y (2006) Filopodia formation mediated by receptor tyrosine kinase Ror2 is required for Wnt5a-induced cell migration. J Cell Biol 175:555-562.

Oishi I, Suzuki H, Onishi N, Takada R, Kani S, Ohkawara B, Koshida I, Suzuki K, Yamada G, Schwabe GC, Mundlos S, Shibuya H, Takada S, Minami Y (2003) The receptor tyrosine kinase Ror2 is involved in non-canonical Wnt5a/JNK signalling pathway. Genes Cells 8:645-654.

Ossipova O, Bardeesy N, DePinho RA, Green JB (2003) LKB1 (XEEK1) regulates Wnt signalling in vertebrate development. Nat Cell Biol 5:889-894.

Ossipova O, Dhawan S, Sokol S, Green JB (2005) Distinct PAR-1 proteins function in different branches of Wnt signaling during vertebrate development. Dev Cell 8:829-841.

Pan CL, Howell JE, Clark SG, Hilliard M, Cordes S, Bargmann CI, Garriga G (2006) Multiple Wnts and Frizzled receptors regulate anteriorly directed cell and growth cone migrations in Caenorhabditis elegans. Dev Cell 10:367-377.

Prasad BC, Clark SG (2006) Wnt signaling establishes anteroposterior neuronal polarity and requires retromer in C. elegans. Development 133:1757-1766.

Rickert P, Weiner OD, Wang F, Bourne HR, Servant G (2000) Leukocytes navigate by compass: roles of PI3Kgamma and its lipid products. Trends Cell Biol 10:466-473.

Romanelli A, Martin KA, Toker A, Blenis J (1999) p70 S6 kinase is regulated by protein kinase Czeta and participates in a phosphoinositide 3-kinaseregulated signalling complex. Mol Cell Biol 19:2921-2928.

Sasaki T, Irie-Sasaki J, Jones RG, Oliveira-dos-Santos AJ, Stanford WL, Bolon B, Wakeham A, Itie A, Bouchard D, Kozieradzki I, Joza N, Mak TW, Ohashi PS, Suzuki A, Penninger JM (2000) Function of PI3Kgamma in thymocyte development, $\mathrm{T}$ cell activation, and neutrophil migration. Science 287:1040-1046.

Sato M, Umetsu D, Murakami S, Yasugi T, Tabata T (2006) DWnt4 regu- lates the dorsoventral specificity of retinal projections in the Drosophila melanogaster visual system. Nat Neurosci 9:67-75.

Schmitt AM, Shi J, Wolf AM, Lu CC, King LA, Zou Y (2006) Wnt-Ryk signalling mediates medial-lateral retinotectal topographic mapping. Nature 439:31-37.

Shi SH, Jan LY, Jan YN (2003) Hippocampal neuronal polarity specified by spatially localized mPar3/mPar6 and PI 3-kinase activity. Cell 112:63-75.

Sivasankaran R, Pei J, Wang KC, Zhang YP, Shields CB, Xu XM, He Z (2004) PKC mediates inhibitory effects of myelin and chondroitin sulfate proteoglycans on axonal regeneration. Nat Neurosci 7:261-268.

Soltoff SP, Rabin SL, Cantley LC, Kaplan DR (1992) Nerve growth factor promotes the activation of phosphatidylinositol 3-kinase and its association with the trk tyrosine kinase. J Biol Chem 267:17472-17477.

Spicer J, Rayter S, Young N, Elliott R, Ashworth A, Smith D (2003) Regulation of the Wnt signalling component PAR1A by the Peutz-Jeghers syndrome kinase LKB1. Oncogene 22:4752-4756.

Stein E, Tessier-Lavigne M (2001) Hierarchical organization of guidance receptors: silencing of netrin attraction by slit through a Robo/DCC receptor complex. Science 291:1928-1938.

Stoyanova S, Bulgarelli-Leva G, Kirsch C, Hanck T, Klinger R, Wetzker R, Wymann MP (1997) Lipid kinase and protein kinase activities of G-protein-coupled phosphoinositide 3-kinase gamma: structure-activity analysis and interactions with wortmannin. Biochem J 324:489-495.

Sun TQ, Lu B, Feng JJ, Reinhard C, Jan YN, Fantl WJ, Williams LT (2001) PAR-1 is a Dishevelled-associated kinase and a positive regulator of Wnt signalling. Nat Cell Biol 3:628-636.

Tao W, Pennica D, Xu L, Kalejta RF, Levine AJ (2001) Wrch-1, a novel member of the Rho gene family that is regulated by Wnt- 1 . Genes Dev 15:1796-1807.

Ui M, Katada T, Murayama T, Kurose H (1984) Selective blockage by isletactivating protein, pertussis toxin, of negative signal transduction from receptors to adenylate cyclase. Adv Exp Med Biol 175:1-16.

Wymann MP, Bulgarelli-Leva G, Zvelebil MJ, Pirola L, Vanhaesebroeck B, Waterfield MD, Panayotou G (1996) Wortmannin inactivates phosphoinositide 3-kinase by covalent modification of Lys-802, a residue involved in the phosphate transfer reaction. Mol Cell Biol 16:1722-1733.

Xiang Y, Li Y, Zhang Z, Cui K, Wang S, Yuan XB, Wu CP, Poo MM, Duan S (2002) Nerve growth cone guidance mediated by G protein-coupled receptors. Nat Neurosci 5:843-848.

Yoshikawa S, McKinnon RD, Kokel M, Thomas JB (2003) Wnt-mediated axon guidance via the Drosophila Derailed receptor. Nature 422:583-588.

Zhang X, Zhu J, Yang G-Y, Wang Q-J, Qian L, Chen Y-M, Chen F, Tao Y, Hu H-S, Wang T, Luo Z-G (2007) Dishevelled promotes axon differentiation by regulating atypical protein kinase C. Nat Cell Biol 9:743-754.

Zhou FQ, Zhou J, Dedhar S, Wu YH, Snider WD (2004) NGF-induced axon growth is mediated by localized inactivation of GSK-3beta and functions of the microtubule plus end binding protein APC. Neuron 42:897-912.

Zhou G, Seibenhener ML, Wooten MW (1997) Nucleolin is a protein kinase $\mathrm{C}$-zeta substrate. Connection between cell surface signaling and nucleus in PC12 cells. J Biol Chem 272:31130-31137.

Zou Y (2004) Wnt signaling in axon guidance. Trends Neurosci 27:528-532.

Zou Y (2006) Navigating the anterior-posterior axis with wnts. Neuron 49:787-789.

Zou Y, Lyuksyutova AI (2007) Morphogens as conserved axon guidance cues. Curr Opin Neurobiol 17:22-28.

Zou Y, Stoeckli E, Chen H, Tessier-Lavigne M (2000) Squeezing axons out of the gray matter: a role for slit and semaphorin proteins from midline and ventral spinal cord. Cell 102:363-375. 